\title{
The Gametophytes, Fertilization and Embryo of Cryptomeria Japonica.
}

\author{
BY \\ ANSTRUTHER A. LAWSON, Ph.D., \\ Instructor in Botany in Stanford University, California, U.S.A. \\ With Plates XXVII-XXX.
}

INTRODUCTION.

T NVESTIGATIONS of the last few years have added much to our I knowledge of the morphology of the Coniferales. Some of the more recent, and probably the most important of these contributions, refer to the family Taxodieae. Arnoldi's observations on Sequoia, Taxodium, Glyptostrobus, Arthrotaxis, Sciadopitys, Cunninghamia and Cryptomeria, while more or less fragmentary in nature, have nevertheless thrown considerable light on the morphology of the gametophytes or embryos of these forms. Coker's work on Taxodium is probably the most complete account of the life-history of any Conifer that has yet been published by one investigator, and constitutes a valuable addition to our knowledge of this group. The present writer's account of the gametophytes of Sequoia sempervirens, which recently appeared in the pages of this Journal, completes the life-history of one of the most important and interesting of the Coniferales.

In addition to the broad phases of morphology that have been brought to light, these investigations have shown quite conclusively that the present family of the Taxodieae is an artificial one, and the genera representing the Taxodieae and Cupresseae should be rearranged. This Arnoldi has already suggested, and he believes that the genus Sequoia should constitute a family by itself, the Sequoiaceae; that Cunninghamia, Taxodium, and Cryptomeria should be placed with the Cupresseae, and that Sciadopitys should constitute a family by itself, the Sciadopitaceae.

While the results of the above-mentioned investigations would seem to warrant such a change, our knowledge of the gametophytes and embryo of the majority of these Conifers is still very meagre. Indeed Taxodium and Sequoia are the only two whose recorded life-histories are approximately complete. It has therefore seemed to me, that before making any

[Annals of Botany, Vol. XVIII. No. LXXI. July, 1904.] 
definite rearrangement of these two families, it might be well to complete, as far as possible, the history of the gametophytes and embryo of some of the most important forms, and this is one of the objects of the present investigations on Cryptomeria Faponica.

Arnoldi ('01) is the only writer who has recorded any important observations on the gametophytes of Cryptomeria, and his account is very incomplete. He finds that the archegonia are arranged just as in the Cupresseae, with a common jacket surrounding the group, but he reports that no ventral canal-nucleus is formed. The pollen-tube is very like that of the Cupresseae. As soon as fertilization is accomplished, the fusionnucleus passes to the bottom of the archegonium, where a number of free nuclei are organized. Cell-walls are formed about the lower nuclei. These cells and nuclei are now arranged in three tiers, the lowest one of which forms the embryo and the middle one the suspensors. The upper tier consists of free nuclei.

\section{MEthods.}

Growing on the campus of Stanford University, there are about a dozen young trees of Cryptomeria Faponica. Collections of cones from these trees furnished most of the material upon which the following investigation is based. Two trees growing near the Hopkins Seaside Laboratory at Pacific Grove furnished the rest of the material. The collections were made during the years I9OI, I9O2 and 1903. During the period of the development of the seed, from October until the following July, collections were made almost daily. Although the trees are young they produce an abundance of male and female cones every year.

The following fixing fluids were employed :

I. Flemming's strong solution.

2. Flemming's weak solution.

3. Flemming's strong solution diluted with one part water.

4. Chrom-acetic mixture.

5. Chromic acid $\mathrm{I} \%$ sol.

Of these, Flemming's weak solution, and strong solution diluted with one volume of water, gave the most satisfactory results, but very good preparations were also obtained by the chrom-acetic mixture. The larger quantity of osmic acid in the strong solution of Flemming caused a considerable shrinkage of the protoplasm and altogether proved unsatisfactory. When this solution was diluted with water the shrinkage was very much diminished, and very good preparations were obtained.

The fixing fluids were invariably taken into the field and the material was killed as soon as the dissections were made. For the early stages the young ovules were removed and killed without further dissection, but after pollination the integument was removed and the nucellus alone was fixed. 
In all the later stages the entire prothallium was removed. Nearly all of the dissections were made while the ovules were immersed in the killing fluid.

After remaining in the fixing fluids from ten to twenty-four hours, the material was washed in running water from four to six hours. In transferring the material through the various grades of alcohol, Schleicher and Schüll's diffusion shells were used in the manner described in my work on Sequoia ('03). Bergamot oil preceded the infiltration of paraffin. Microtome sections from $2 \mu$ to $8 \mu$ in thickness were made and the albumen fixative was used. For differentiating the various cell-structures, the triple stain, safranin gentian violet and orange $G$, gave the most satisfactory results.

\section{The Male Gametophyte.}

The staminate cones make their appearance as early as the first week in October, although pollination does not take place until March of the following spring. During the latter part of October and the early part of November, male cones in all stages of development may be found. From collections made during this period it was found that the reduction division of the microspore mother-cell, which leads to the formation of the tetrads, occurs about the first week of November. This, however, is not always the case, for we frequently find well-developed pollen-grains and very young sporangia not yet showing the mother-cells in the same cluster of cones. Generally the tetrads have separated and the pollen-grains are formed before the first of December.

At first the microspores are more or less spherical in form, are surrounded by a thin membrane, and contain a deeply staining centrally situated nucleus (Pl. XXVII, Fig. I). Very soon after they are formed they enlarge slightly and the thin membrane develops into a hard thick wall. During the thickening of the wall a small hook-like projection is developed from one side, as shown in Fig. 2. About four or five weeks before pollination, the nucleus of the pollen-grain enlarges and prepares for division. The spindle showing this division was not found, but material collected at this time showed two distinct nuclei in each pollen grain. One of these nuclei is much larger than the other. The larger one was generally found near the centre of the spore, while the smaller one was very frequently found lying against the spore-wall. The cytoplasm surrounding the smaller nucleus was much more dense than the rest of the cytoplasm in the spore. I am indebted to Professor Campbell ${ }^{1}$ for calling my attention to the plasmic membrane which separates the two nuclei, and which I was at first unable to detect. Fig. 3 represents a section of the pollen-grain soon after it reaches the micropyle; by this time the plasmic

1 Campbell's University Textbook of Botany, 1902, p. 324.

G $\mathrm{g}$ 
membrane between the nuclei has disappeared, and the cytoplasm surrounding the latter is very granular but uniform throughout.

In the Cycads, Ginkgo, Pinus and Podocarpus, one or more vestigial vegetative cells of the gametophyte have been observed in the pollen-grain. As far as I have been able to make out, no such cells are organized in Cryptomeria. From daily collections made during the entire period of the development of the male gametophyte, close observation failed to reveal any trace of a vegetative cell or of a nucleus representing such a cell. In this respect the pollen-grain of Cryptomeria resembles that of Thuja (Land, '01), Taxodium (Coker, '03), and Sequoia (Lawson, '04). Not only at the time of pollination, but for about three weeks after the microspores have been received at the apex of the nucellus, there are but two nuclei present in each spore. The later history of the larger of these proved it to be the tube-nucleus, and the smaller one, no doubt, represents the generative cell.

During the latter half of February, when the female flowers first become visible, the microsporangia open and the pollen is liberated. For about two weeks the branches of the trees are quite yellow from the great quantities of pollen that have fallen on them. As the female flowers are open at this time, it is practically impossible for them to escape the reception of the pollen. Longitudinal sections of the female flower taken at this stage showed the integument of the ovule extending slightly above the level of the apex of the nucellus, leaving the micropyle open. From three to eight pollen-grains were always found deposited on the apex of the nucellus. As in Sequoia, the pollen-grains retain this position for about three or four weeks without further changes. The upper portion of the integument grows over the pollen-grains and closes the micropyle in very much the same manner as it does in Sequoia. The epidermal and subepidermal cells lining the micropyle lengthen towards the centre of the latter until they finally meet and the micropyle is closed. Fig. 9 shows the micropyle nearly closed.

Very soon after the casting off of the thick outer wall of the pollengrain, the tube pushes out and immediately penetrates the tissue at the apex of the nucellus. It will be remembered that in Sequoia (Shaw, '96 ; Arnoldi, '01; Lawson, '04), many of the tubes do not penetrate the nucellar tissue immediately, but grow down between the integument and the nucellus. This is clearly not the case in Cryptomeria. Fig. 7 shows at least four tubes penetrating the nucellar tissue at the apex. An examination of hundreds of tubes failed to reveal any indication of branching. The tubes grow directly downward towards the developing female prothallium. Fig. 8 shows a typical tube; the tube- and stalknuclei and the body-cell are at the tip, and are about to be discharged into the depression above the archegonium-complex. In the course of 
their development, they deviate very little out of the straight line towards the female prothallium. As shown in Fig. 8, the cells of the nucellar tissue through which the tube passes become disorganized, and are probably absorbed by the developing tube. There are usually five or six pollen-tubes present, and by the time they reach the female prothallium, the upper portion of the nucellus has a very disorganized appearance (Fig. 7). As the tube advances the tube-nucleus is always found near the tip.

Soon after the penetration of the tube both the nuclei within it enlarge considerably and advance with the growing tube. The generative nucleus is always a little in the rear of the tube-nucleus. Before the tube has penetrated very far the generative nucleus divides, and the young pollentube has now three free nuclei. Of the two nuclei derived from the generative nucleus, it is impossible to say which is the stalk- and which is the body-nucleus, as they are of equal size. One of them, however, very soon enlarges and becomes surrounded by a dense zone of granular cytoplasm, in which innumerable starch-granules are imbedded. The future activity of this nucleus proved it to be the body-nucleus, and the sister-nucleus which failed to enlarge is no doubt the so-called stalk-nucleus.

The body-nucleus eventually becomes several times the size of the stalk-nucleus, and, as it grows, the cytoplasm surrounding it becomes much more dense. A membrane is now formed at the periphery of the dense zone, and a distinct body-cell is organized, which becomes perfectly spherical. The thickness of the dense zone of cytoplasm within the bodycell-membrane is about half the diameter of the large, centrally situated nucleus as shown in Fig. 4. The tip of the tube now contains one large spherical cell and two free nuclei. These three structures always lie near each other in a central strand of cytoplasm. The relative positions and size of these structures is shown in Fig. 4. The lower free nucleus (marked t.n.) is the tube-nucleus. Immediately above this is the stalk-nucleus (marked s.n.), and slightly in the rear is the large body-cell (marked b.c.). These three structures remain in close proximity to each other till about the middle of June, when the two male cells are organized. When fully mature, the nucleus of the body-cell is at least four times the size of the tube- or stalk-nuclei. It contains a very large nucleolus, and the chromatin at this time appears in the form of coarse, deeply staining granules suspended on threads of linin. The cytoplasm surrounding the bodycell and the tube- and stalk-nuclei is very coarsely granular, but free from starch. Within the body-cell large quantities of starch-grains are always present.

It takes the tube about three or four weeks to reach the female prothallium, and during this period the body-cell undergoes no more 
perceptible changes. During the first week in June, however, when the tip of the tube with its contents has reached the depression just above the archegonium-complex, the nucleus of the body-cell prepares for division. It first enlarges slightly, the nucleolus disappears, and the chromatin loses its granular appearance and assumes the form of a coarse continuous thread, which winds irregularly through the karyolymph. A very careful study of the cytoplasm was made at this stage. Apart from the irregular distribution of the starch-grains, the cytoplasm surrounding the nucleus appeared to be perfectly uniform. No differentiation that would suggest the presence of the blepharoplasts reported for Cycas (Ikeno, '97), Zamia (Webber, '97), and Ginkgo (Hirasé, '95) could be found. Coker ('03) has recently reported the presence of light areas at the poles of the cells in Taxodium, but he further states that the resemblance of these areas to blepharoplasts is 'confined entirely to their position.' It must be remembered that these centrosome-like structures have only been found where the male cell develops cilia, and that their function is confined to the organization of these motile organs. Where the pollen-tube acts as the carrier of the male cells to the archegonia, motile organs are no longer necessary. Cilia in connexion with the male cells of Coniferales have never been observed, and it is therefore not surprising that the structures responsible for their formation should also be missing.

The stages showing the organization of the spindle which divides the body-cell were not found, but several sections showed the daughter-nuclei at the poles with the kinoplasmic fibrils between them. Fig. 5 shows a stage where the daughter-nuclei are completely organized, and the plate which divides the cell into two is forming at the equator. Several sections showing the development of the plate were examined, and it is apparently organized from the kinoplasmic fibrils which stretch between the daughternuclei. The daughter-nuclei now enlarge considerably, and each contains two or three nucleoli with the chromatin in the form of coarse granules suspended on threads of linin (Fig. 5). During the division of the nucleus, the body-cell loses its spherical form, and becomes more or less elliptical, as shown in Fig. 5 .

Soon after its complete organization the cell-plate splits, and the two male cells are free and separate from each other. As shown in Fig. 6, they are flat on one side and rounded on the other. They remain close together for some time, but when they separate they become spherical in form. The nucleus of each becomes very large, its diameter being about half the diameter of the cell. The chromatin is in the form of small, irregularly shaped granules suspended in a network of linin. The two male cells are of the same shape and of equal size, and, as we shall point out under the head of fertilization, they are both functional. 
With the complete organization of the male cells, the history of the male gametophyte ends, and this is true for all other Conifers that have been investigated except Sequoia (Lawson, '04). In this latter there is the additional step of the discharge of the male cell-nucleus into the archegonium. In Cryptomeria the entire male cell enters the archegonium as shown in Fig. 43. As we shall point out later, the two male cells enter separate archegonia, and therefore one pollen-tube brings about the fertilization of two egg-cells.

The general characters of the male gametophyte of Cryptomeria are more distinctly of the Cupresseae type than of the Taxodieae. The behaviour of the pollen-tube and its spermatogenesis are very unlike Sequoia. Compared with Thuja (Land, '02) and Taxodium (Coker, '03) there is a very striking similarity.

\section{The Female Gametophyte.}

The stages in the development of the macrosporangium and the integument follow very closely those in Taxodium (Coker, '03) and Sequoia (Shaw, '96, Lawson, '04). There is one striking difference, however, and that is the advanced stage in the development of the integument before the differentiation of the sporogenous cells in the nucellus. Fig. 9 shows the appearance of the nucellus and integument in section from material collected March 7. As a rule, however, the micropyle is much more open than that shown in the figure. Material collected before March 6 showed no trace whatever of sporogenous cells in the nucellus, although the integument extended considerably beyond the apex of the nucellus, and in several cases the micropyle was found to be closed, shutting the pollen-grains within. The closing of the micropyle is brought about in very much the same manner as in Sequoia. The sub-epidermal cells and the epidermal cells in the upper region of the integument which form the inner wall become very much elongated in a direction at right angles to the micropyle. The result is that as these cells elongate, the micropyle becomes smaller until the channel is finally closed completely.

One series of sections taken during the first week in March showed an interesting abnormality. There were two distinct sporangia developed within a single integument. This is shown in Fig. Io. These twin sporangia were not sufficiently developed to show the sporogenous cells, and as they were the only ones found out of the hundreds of preparations studied, they are no doubt abnormal and very exceptional,

The sporogenous cells become differentiated early in March. It is very difficult at first to distinguish them from the ordinary sterile cells of the sporangium, but they soon become very densely packed with starch-granules, and become five or six times as large as the sterile cells 
immediately surrounding them. Their nuclei increase correspondingly, and become very conspicuous when compared with the small nuclei of the sterile tissue. There are always one or two large, deeply staining nucleoli present, and the chromatin is in the form of small granules suspended on a network of linin as shown in Fig. I2.

There are usually three or four sporogenous cells differentiated, and these are always situated near the base of the sporangium just a little above the point of insertion of the integument. The position and relative size of the sporogenous cells is well shown in Fig. II. According to Coker ('03) but a single megaspore mother-cell is organized in Taxodium. In this respect Cryptomeria resembles Sequoia, where a group of five or six mother-cells are organized (Shaw, '96, Lawson, '04). Another striking difference between Cryptomeria and Taxodium is that in the latter (Coker, '03) there is a distinct zone of large-celled tissue or tapetum surrounding the large spore mother-cell, which persists up to the time of endosperm-formation. According to Coker, the function of this largecelled tissue is to nourish the young gametophyte. It is therefore regarded as a tapetum, which, instead of becoming disorganized upon the germination of the megaspore, continues to grow with the developing prothallium, and nourishes the latter until the endosperm is fully formed. I was unable to find anything that resembled this in Cryptomeria. Surrounding the three or four mother-cells, there is present a layer of small elongated cells which have the appearance of being crowded by the growing sporogenous cells. Soon after the spores are formed these elongated cells become disorganized and are probably absorbed by the germinating spore. The general appearance of the cells surrounding the megaspore mother-cells is shown in Fig. I2.

Upon their complete organization the three or four mother-cells immediately prepare for division. This is the reduction-division which marks the beginning of the female gametophyte. In Pinus (Coulter and Chamberlain, '01), the single mother-cell gives rise to a row of four potential megaspores. In Larix europaea (Strasburger, '79), there are at least three potential spores formed from the mother-cell. In Larix Sibirica Juel ('00) finds that the first division of the single mother-cell is heterotypic, and the number of chromosomes is just half the number present in the nuclei of the nucellus. Each of the daughter-nuclei now divides by a homotypic division with the same reduced number of chromosomes. There is thus formed from the single mother-cell a row of four megaspores, the lowest of which germinates and gives rise to the prothallium. In Sequoia (Shaw, '96, Lawson, '04) there are five or six mother-cells organized, each of which divides twice and gives rise to four potential spores. In Taxodium (Coker, '03) there are two cells formed as a result of the first division of the single mother-cell, but only the lower one of these divides again. 
The result is that there are only three potential spores formed from the mother-cell.

As stated above, there may be three or four megaspore mother-cells organized in Cryptomeria. As the early stages of the spindles of the first division were not found, I was unable to study the behaviour of the chromatin. Fig. I 3 shows a spindle of the first division of one of the mother-cells with the daughter-nuclei already organized at the poles. The next stage observed showed a large group of spores as illustrated in Fig. I4. The contents of these megaspores were devoid of starch, and quite different in appearance from those of the mother-cells. They varied from twelve to sixteen in number, showing without much doubt that each mother-cell gives rise to four megaspores. As shown in Fig. I4, the one that is more centrally situated becomes larger than the others, and it probably is the only one that germinates. As this central megaspore increases in size, free nuclear division proceeds at a rapid rate. Meantime the other spores show all stages of disorganization, and are very probably absorbed by the young prothallium. These early stages in the development of the gametophyte progress slowly, for about a month after the organization of the megaspores we find the condition represented in Fig. I5. It will be observed from this figure that the greatest growth of the young prothallium has taken place in the direction of the chalaza. There are a number of vacuoles present, and the numerous free nuclei are distributed irregularly throughout the strands of cytoplasm. Up to this time the conditions are very much the same as those observed in Sequoia (Lawson, '04).

As the young prothallium increases in length, the vacuoles increase in size, and eventually flow together, forming one very large central vacuole as in Sequoia (Arnoldi, '01 ; Lawson, '04), Taxodium (Coker, '03), Taxus and other Conifers. The result of this is that the cytoplasm is crowded to the wall, and appears in the form of a very thin parietal layer, in which the free nuclei lie imbedded at more or less regular intervals, as indicated in Fig. 16. A higher magnification of the parietal layer is shown in Fig. I9. It will be seen that the thickness of the cytoplasmic layer is just about equal to the diameter of the nuclei.

The most striking difference between the young female gametophytes of Sequoia and Cryptomeria up to this stage is in the entire absence in the latter of any secondary prothallia. It will be remembered that in Sequoia one or two secondary prothallia, while failing to produce true prothallial tissue, nevertheless reach an advanced stage of development. In Cryptomeria only one of the megaspores germinates, and there is consequently but one primary prothallium formed.

The next stage in the development of the prothallium showed a considerable increase in the thickness of the parietal layer of cytoplasm, and 
this is accompanied by an increase in the number of free nuclei. As the free nuclei continue to divide, delicate membranes are formed between them, and they now take up a position at the inner layer of cytoplasm exposed to the cell-sap of the large central vacuole. This condition is shown in Fig. I7. The membranes formed between the nuclei are very delicate, and all lie more or less parallel to each other. A higher magnification of this stage is shown in Fig. 20. It will be seen that the primary cells thus formed are open on the inner side, exposing the cytoplasm to the vacuole. These structures are the so-called 'Alveoli,' first described by Mlle. Sokolowa ('91) in Pinus, Cephalotaxus, and Funiperus, and since found in other Gymnosperms by Ikeno ('98), Arnoldi ('00), and Coker ('03). Coker's objection to the term 'Alveoli' is well taken, but the term he substitutes, 'prothallial tubes,' is almost as misleading, for these structures are not always tubular. They constitute the first cells of the prothallium, and although they are open on one side and are later multinucleate, they are nevertheless cells. To avoid confusion I will therefore use the term 'primary prothallial cells' to designate these structures.

Fig. 20 indicates the manner in which the primary prothallial cells are formed. Comparing Figs. I9 and 20, it is obvious that the nuclei have divided and that a delicate membrane has been formed in the region of the equator of the spindle, midway between the daughter-nuclei. A section taken parallel to the inner surface of the parietal layer of cytoplasm is shown in Fig. 22. This is looking down into the cells, and their outline and the method in which the membrane is formed are easily made out from this view.

The primary prothallial cells thus organized elongate towards the centre of the vacuole in very much the same way as Mlle. Sokolowa ('91) has described for other Conifers ; the nuclei retaining their position at the inner exposed surface. By the time the prothallium has reached the stage shown in Fig. 18 , the nuclei in the primary prothallial cells have divided repeatedly and very delicate membranes have formed between them. The method of the formation of these membranes is shown in Figs. 20 and $2 \mathrm{I}$. They evidently develop from the continuous fibrils of the spindle which extend between the daughter-nuclei. As numerous cross-walls are formed, all of the primary cells do not extend inward as far as the vacuole. But they all now proceed to elongate and grow towards the centre of the diminishing vacuole. As this growth continues the vacuole becomes smaller and smaller until the space it occupied is closed by the union of primary prothallial cells at the centre. During this period the nuclei divide freely so that the cells are all multinucleate. Fig. 23 represents a longitudinal section of the upper position of the prothallium at this time. As shown in the figure, the walls of the cells are extremely delicate and may not 
extend all the way to the centre of the prothallium. Now these delicate membranes take no part whatever in the formation of the cell-walls of the permanent prothallial tissue. As we shall proceed to demonstrate, these permanent cell-walls originate in quite another way.

By the time the central vacuole has been completely closed by the ingrowing primary cells, the nuclei continue to divide without the formation of walls between them. As the membranes of the primary cells do not extend all the way across, the median region of the prothallium consists merely of numerous nuclei lying freely in the cytoplasm. These free nuclei, as well as those in the primary cells, now undergo a peculiar division, which results in the formation of permanent cell-walls. The manner in which these walls are formed is extremely interesting, and unlike anything that has so far been reported for the Gymnosperms. Sections of the prothallium at this time showed hundreds of the free nuclei in all stages of mitosis. The early stages in the development of the spindle clearly showed the multipolar character, indicating that they follow the same general method that prevails in the Angiosperms. As shown in Fig. 24, the mature spindle is quite narrow and sharply pointed at the ends. When the chromosomes reach the poles, numerous kinoplasmic fibrils stretch between them (Fig. 25), and by the time the daughter-nuclei are organized, these fibrils increase in number and curve outward on all sides. This condition is shown in Figs. 26, 27, 28. Ordinarily we should expect to find the cell-plate formed from these fibrils midway between the two daughternuclei, but this does not occur. The fibrils continue to increase in number and curve outward still further as shown in Figs. 29, 30. This process continues until both daughter-nuclei are completely surrounded by a sheath of fibrils. Of the somewhat spherical structure thus formed, the fibrils are all at the periphery and the nuclei are within, one at each end and surrounded by ordinary cytoplasm. Fig. $3^{\mathrm{I}}$ shows the appearance of one of these structures in cross-section-that is at right angles to the long axis of the spindle. The fibrils in section appear as small dots closely packed together, and arranged in a dense zone which completely encircles the two nuclei (Fig. 32). From this view the two nuclei cannot be seen at the same focus. The fibrils which compose these peculiar kinoplasmic structures fuse laterally with one another and are gradually converted into a permanent cell-membrane, which completely encloses the two nuclei. As these divisions of the free nuclei occur almost simultaneously, the prothallium at this time presents a most extraordinary appearance. The process goes on throughout the whole of the prothallium except in the region of the archegonial initials. All stages in the process could be observed in a single section. Fig. 24 represents a portion of the prothallium at this time. Although this division brings about the formation of the first permanent cell-membranes in the endosperm, no cell-plate is developed between the daughter-nuclei as 
ordinarily occurs after mitosis. The result of this is that the prothallium passes through a stage when the majority of its cells are binucleate.

When first formed, the membranes surrounding the pairs of nuclei appear round or oval in section. As hundreds of them are formed they become more or less crowded and the walls become flat where they press upon each other. As they crowd against one another, the neighbouring walls become fused together, and this gives the appearance of ordinary cellular tissue. Fig. 33 shows a portion of the prothallium soon after this division. There are two distinct nuclei in each cell.

As far as I am aware such a peculiar method of endosperm-formation has not been recorded. Indeed I do not know where such a type of free cell-formation occurs in the plant kingdom. The nearest parallel to it is that which Harper (' 97 and '00) has described in the development of the ascospores in the ascus of Erysiphe and Pyronema. In these Fungi, after the last division of the spore-mother cell, the kinoplasmic fibrils which radiate out from the centrosome bound off the ascospores by a process of free cell-formation. These fibrils increase in number, and as they grow in length they curve around the nucleus. By fusing together laterally the fibrils are converted into a complete membrane which surrounds the young ascospore. Between this process and that which I have described in the endosperm of Cryptomeria, there is a striking similarity; the main difference being that it is the astral rays in Erysiphe and Pyronema which form the membrane, while in Cryptomeria it is the continuous fibrils of the spindle which are converted. They also differ in the absence of the centrosome in Cryptomeria, and also in the enclosure of two nuclei instead of one.

The earlier stages in the development of the female prothallium in Cryptomeria agree very closely with those reported for many other Conifers, but this later stage, where such a peculiar form of free cell-formation precedes the formation of the permanent endosperm-tissue, is unlike anything that has heretofore been described. That it is normal in Cryptomeria I feel tolerably certain. It was found in a large number of preparations of material collected from several different trees and during both years, I 902 and 1903 . Whether or not it occurs in other Conifers can only be learned from future investigations.

After the binucleate cellular tissue has been thoroughly established in the endosperm, nuclear division proceeds in the usual way and the cellplates are formed between the daughter-nuclei. Some preparations, however, showed binucleate cells in the endosperm as late as the early stages of the embryo. 


\section{The ARCHEgonia.}

The archegonial initials were first observed in material collected about May 25, just before the prothallial tissue is thoroughly organized. They are always situated at the apex of the prothallium ; and are generally peripheral cells, but some were frequently found one or two layers of cells below the periphery. They are very easily distinguished from the other cells of the prothallium by their large size and deeply staining granular cytoplasm. The nucleus is also very conspicuous, being fully twice the size of the nuclei of the surrounding sterile cells. A group of the initials is shown in Fig. 34. At first the nucleus is centrally situated and the lower part of the cell is vacuolated.

The further development of the archegonium is very rapid and only a few preparations showed the most important stages. When they first become differentiated, the nucleus is nearly always centrally situated. About the time the vacuole develops, the nucleus moves towards the periphery of the cell and immediately prepares for division. Several preparations showed the spindle, and in each case it was found very near the periphery and always parallel with the long axis of the cell. This division results in the organization of the central cell and the primary neck-cell of the archegonium. A complete wall cuts off the primary neckcell and the central nucleus moves back to a position just above the vacuole. From the beginning the primary neck-cell is many times smaller than the central cell.

Very soon after the primary neck-cell has been cut off, the central cell enlarges considerably, especially at the base, and the region surrounding the vacuole becomes very much wider than the narrow tapering region towards the neck. Meantime the cytoplasm becomes very densely granular, and the nucleus, which is centrally situated, increases very much in size, and the condition of the chromatin shows that the nucleus is preparing for further division.

During the development of the central cell, the primary neck-cell undergoes some interesting changes. It does not increase in size, but its cytoplasm is densely granular and stains very readily and can therefore be easily distinguished from the neighbouring sterile cells. The nucleus now very soon divides, and a wall is formed between the daughter-nuclei at right angles to the wall which cuts off the primary neck-cell from the central cell. Fig. 35 shows the primary neck-cell just after its nucleus has divided; the wall between the daughter-nuclei has not yet been organized. The archegonium has now two neck-cells, and these were very easily distinguished in longitudinal sections. Indeed longitudinal sections of all later stages showed but two cells in the neck. A study of cross-sections, however, showed very conclusively that each of the two neck-cells divide 
again at right angles to the first division. The mature archegonium has therefore at least four cells in the neck. These are shown very well in Fig. $3^{8}$, as they appear in cross-sections. In but a single case was I able to find a variation from this number, and that was in a longitudinal section where four were observed, suggesting that there may have been eight altogether. It appears that in the Conifers the number of neck-cells is not always constant. According to Coker ('01), they may vary from two to twentyfive in Podocarpus. In Sequoia (Lawson, '04) they may be two to four. In Taxodium (Coker, '03) they vary from two to sixteen or more, and they also vary in Tsuga (Murrill, '00). In Cryptomeria the neck consists typically of a single tier of four cells (Fig. $3^{8}$ ).

By the time the neck-cells have been organized the central nucleus enlarges considerably, and shows all the characteristics of a nucleus preparing for division. Fig. 4I shows a section of the nucleus in this condition. The large nucleolus has disappeared and the chromatin has assumed the form of definite chromosomes. The spindle showing the actual division of the central nucleus, and which gives rise to the egg and ventral canalnucleus, was not found; but from the observations made it seems tolerably certain that such a division takes place. Many archegonia at this stage showed two distinct nuclei, and one of these is shown in Fig. 36 . The results of investigations during the last few years make it appear that the cutting off of the ventral canal-cell or nucleus is very general, if not universal, among the Conifers. Such a cell or nucleus has been found in Funiperus (Strasburger, '79, Belajeff, '93); Pinus (Blackman, '98, Chamberlain, '99, Ferguson, '01); Taxodium (Coker, '03); Podocarpus (Coker, '02); Tsuga (Murrill,'00); Thija (Land,'02); Sequoia (Lawson, '04); and Picea (Miyake, '03). In many of these forms all the stages of mitosis have been carefully followed, so that there can be little doubt that such a division of the central nucleus occurs in these Conifers. Owing to the fact that Arnoldi denies the existence of a ventral canal-cell or nucleus in Cryptomeria, I have been very careful in my observations. Although I was unable to find the spindle, there was nevertheless enough evidence to convince me that such a division takes place. In a large number of archegonia, just before fertilization, two distinct nuclei were observed in the cytoplasm. That this second nucleus was not the male nucleus in the act of fertilizing the egg was very obvious, from the fact that the neck-cells were in no way disturbed, and in nearly every case the male cells were to be seen in the pollen-tube above the archegonia. When we consider that the stage immediately preceding this showed the central nucleus preparing for division, I have little hesitation in considering the second nucleus in the archegonium to be the ventral canal-nucleus. In Fig. 36, the ventral canalnucleus is already showing signs of disorganization. It presumably lasted but a short time, for it was not found in the stages during or after fertiliza- 
tion. Fig. 37 represents a typical mature archegonium ready for fertilization. The egg-nucleus is at this time always centrally situated, and below this is a large vacuole. With the exception of the character of the neck-cells the mature archegonium of Cryptomeria is strikingly like that of Thuja (Land, '01) and Taxodium ('03), and, as we shall see below, the grouping of the archegonia is distinctly of the Cupresseae type.

In regard to the distribution of the archegonia, my observations agree very closely with those of Arnoldi ('01). They are grouped in exactly the same way as in the Cupresseae. The number varies from eight to fifteen, and they nearly always form a single compact group at the apex of the prothallium as shown in Fig. 39. The necks of the archegonia are not on a level with the tip of the prothallium, but open into a very distinct depression, as indicated in Fig. 39. In longitudinal sections only four or five of the archegonia may be seen, but cross-sections show the entire number and also the way they are arranged. Fig. 40 represents a cross-section of the prothallium in the region of the nuclei of the archegonia.

As reported by Arnoldi ('01), there is a common jacket surrounding the group of archegonia. The jacket-cells extend nearly as far as the neck, and for a considerable distance constitute but a single layer. Towards the base there may be two or three layers of jacket-cells, but at the base and below the archegonia there are several layers of them. Not infrequently the jacket-cells were found extending a little way up between the archegonia, and occasionally, as shown in Fig. 39, they extended quite as far as the neck-cells, thus completely separating one or two of the archegonia from the main group.

The jacket-cells themselves showed some interesting features. The cytoplasm is always densely granular and stains exactly like the cytoplasm of the egg. The nuclei are very conspicuous and stain much more intensely than those of the other sterile cells of the prothallium. The jacket-cells at the base of the archegonia are small and are crowded closely together, while those extending up between the archegonia vary considerably as to their size ; some growing to fully half the size of the archegonium. By the time that the archegonia are mature, nearly all of the jacket-cells are multinucleate. All stages of nuclear division were found in the cells, and they showed the characteristics of ordinary normal mitosis. There may be as many as five or six nuclei in each jacket-cell. Another conspicuous characteristic of these cells was the presence of a large vacuole towards one end (Fig. 42). If the larger of the jacket-cells were not multinucleate, they would be strikingly like small archegonia.

It will be remembered that in Sequoia the jacket-cells are very irregularly distributed, and that in certain stages it is quite impossible to distinguish them from young archegonia. In my work on Sequoia ('04) I pointed out the common origin and general similarity of the 
jacket-cells and archegonial initials, and suggested that the jacket-cells were sterile archegonia. The fact that the jacket-cells are multinucleate in Cryptomeria does not argue against this view, but rather strengthens it. If the jacket-cells are archegonial initials morphologically, and their generative functions changed to one of nourishing, we ought not to expect nuclear activity to be entirely suppressed. From this point of view, I regard the various nuclei in the jacket-cell as representing the abortive nuclei of the egg, ventral canal-cell and neck-cells.

In this connexion, it is interesting to note that in Sequoia, where the archegonia are very numerous, the jacket-cells are less highly differentiated; and in forms like Pinus, where the archegonia are very few, the jacket-cells become very highly specialized as nourishing cells, and even have (according to Goroschankin, '83) a direct communication with the cytoplasm of the central cell.

\section{Fertilization.}

We have already described how the pollen-tube grows directly downward through the tissue at the apex of the nucellus until it reaches the tip of the prothallium. There may be as many as four or five pollen-tubes, and their ends reach the depression above the archegonium-complex some little time before the archegonia are completely organized. The tubes all grow towards this common point, and when they reach the apex of the prothallium there may be as many as ten male cells situated immediately outside the neck-cells. Fertilization is therefore very easily accomplished.

In many Conifers the process of fertilization becomes very much complicated by the entrance of other pollen-tube structures than the male cell into the archegonium. In Pinus nearly the whole of the contents of the pollen-tube passes into the archegonium (Goroschankin, '83 ; Dixon,'94 ; Blackman, '98 ; Ferguson, '01 ; Coulter and Chamberlain, '01) ; a similar condition has been found in Taxodium (Coker, '03; Cephalotaxus (Arnoldi, '00), and in Picea excelsa (Miyake, '03). In Picea vulgaris, Strasburger ('84) reports that two male cells enter one archegonium. In Thija, Land ('02) finds that the tube- and stalk-nuclei may occasionally enter the archegonium, but they more generally remain outside and become disorganized in the cavity above the archegonium-complex. From these recorded observations it appears that the fertilization of many Conifers at the time of fusion of the male and female nuclei becomes very much complicated by the presence of other pollen-tube structures in the archegonium which take no essential part in actual fertilization. In Sequoia (Lawson, '04), however, quite a different and much more simple process prevails. Here only the nucleus and a very small amount of cytoplasm of the male cell enters the archegonium, so that at the time of fusion only the 
two sex-nuclei are present in the archegonium. In this respect Sequoia differs from all other Conifers that have been investigated.

In Cryptomeria only one male cell enters the archegonium. Although a great many preparations showing all stages of fertilization were studie d no exception to this rule was found. Just before fertilization, the archegonia are very similar to those described by Coker ('03) for Taxodium; they differ only in the character of the neck-cells. There is a large central nucleus containing a chromatin network and one or two nucleoli. Just below the nucleus there is a large vacuole. Fig. 37 shows a mature archegonium ready for fertilization. Cross-sections of the neck at this time showed a distinct space between the neck-cells, indicating that they were preparing for the entrance of the male cell by separating from each other, as shown in Fig. $3^{8}$. The actual entrance of the male cell was not observed, but several preparations showed it just inside the archegonium. In these cases the neck-cells were forced from their position and were more or less disorganized. Upon its entrance, the male cell loses its spherical form. As shown in Fig. 43, it is nearly twice as long as broad, and completely fills the upper part of the archegonium. The cytoplasm is very densely granular and contains an abundance of starch-grains. The membrane surrounding the male cell remains intact for some little time after it enters the archegonium, and its nucleus is just about half the size of the egg-nucleus.

As the male cell advances towards the egg-nucleus, the membrane surrounding it disappears and its cytoplasm unites freely with that of the egg. The male nucleus enlarges and immediately moves towards the female nucleus. At this time the male nucleus is not quite as large as the female, but their structure is similar. The chromatin is in the form of small granules suspended on an irregular network of linin. They also stain equally dense with safranin or gentian violet. The only distinction between the male and female is their size and position.

The male nucleus now flattens itself against the female in the manner shown in Fig. 44. As it does so, it evidently increases in size, for the next stage showed the condition illustrated in Fig. 45. As indicated in the figure, the male nucleus has so far forced in the wall of the female that it is almost completely enveloped by the latter.

During this period, the cytoplasm of the two sex-cells becomes very intimately united, and the starch-granules brought in by the male cell collect and form a very dense zone around the fusing nuclei. This condition is strikingly similar to that described by Coker ('03) for Taxodium.

In Pinus, according to Blackman ('98), the first segmentation-spindle begins to develop before the sex-nuclei lose their identity. This has been at least partially confirmed by Chamberlain (1899) and Ferguson ('01). A similar condition has been found by Woycicki ('99) in Larix. In these 
forms the chromatin of the male and female nuclei may be distinguished inside the wall of the female nucleus; the fusion of the two taking place very slowly. In Cryptomeria the process of fusion is more rapid. As shown in Fig. 45, the male and female nuclei only retain their identity by the presence of the nuclear membrane between the two. The chromatin contents of the nuclei are structurally alike, and as soon as the membrane separating them breaks down the male can no longer be distinguished from the female. In this particular process, Cryptomeria resembles Sequoia. When the membrane between the nuclei disappears, the chromatic contents of the two mingle together and form the common network of the fusionnucleus. The fusion-nucleus was frequently met with, and this has convinced me that there is at least a short resting period before the organization of the first segmentation-spindle. Fig. 49 shows the fusion-nucleus with the chromatin evidently in the resting condition. It has been reported that in Taxodium (Coker, '03) and in Taxus (Jäger, '99) the fusing nuclei travel to the base of the egg before the first division occurs. In Cryptomeria this is clearly not the case, for the first segmentation-spindle was always found at the centre of the egg, just about the point where the fusion of the nuclei took place.

It has been stated above that each fertilized archegonium receives but a single male cell, although there are two of the latter formed in each pollentube. We have now to complete the history of the second male cell. In many Conifers, especially in those forms where the entire contents of the pollen-tube pass into the archegonium, only one of the male cells is functional. This has been observed in Pinus (Blackman, '98), Cephalotaxus (Arnoldi, '00), Picea (Miyake, '03), Podocarpus (Coker, '02), and it may sometimes occur in Taxodium (Coker, '03). In these cases a pollentube can bring about the fertilization of but one archegonium. In other forms where both male cells are functional, as in Funiperus (Strasburger, '79), Sequoia (Lawson, '04), and generally in Taxodium (Coker, '03), two archegonia may be fertilized from the contents of one pollen-tube. In Cryptomeria, where so many male cells from the various pollen-tubes are gathered together in the depression immediately above the archegoniumcomplex, it was difficult to distinguish the second male cell from those of the other tubes, as they are all of the same size and shape. As nearly all of the archegonia were fertilized, however, it seems extremely probable that both male cells are functional, and that two archegonia are fertilized by one pollen-tube.

\section{THe Embryo.}

Although the fusion of the male and female nuclei results in a distinct resting fertilized nucleus, the resting period is a short one. The uniform chromatin network of the fusion-nucleus very soon undergoes a change 
which is characteristic of nuclei preparing for division. It assumes the form of definite chromosomes. The stages in the formation of the first segmentation-spindle were not observed, but the mature spindle was frequently met with. Arnoldi ('01) reports that the first division takes place at the base of the archegonium, Coker ('03) reports the same condition for Taxodium. I was unable to confirm the observations of these writers, for every case examined showed the first segmentation-spindle in the middle of the archegonium just about the place where the fusion of the sex-nuclei occurred.

The dense zone of starch-granules which surround the fusion-nucleus persists until the completion of the first division. Fig. 46 shows the first segmentation-spindle completely surrounded by the zone of starch-granules. This gives the impression that the spindle is organized within the nuclear membrane, but a very close examination failed to reveal a trace of the latter. The first spindle is a little larger than those formed in the proembryo and embryo. It is very sharply pointed at the poles and broad at the equator, as shown in Fig. 46. Only a few of the chromosomes are shown in this figure; the majority of them were found in the sections immediately following the one from which the figure was drawn.

The chromosomes of the pro-embryo are very long, V-shaped structures. They are always attached to the spindle-fibrils at the point where the arms of the $\mathrm{V}$ meet. They are just about one-fourth the length of the spindle, for when they are situated at the equator, they extend half-way to the pole. Fig. 47 shows a spindle of the second division of the pro-embryo with the chromosomes approaching the poles. On account of the presence of the two long arms which overlapped each other more or less, it was practically impossible to accurately estimate the number of the chromosomes. There are approximately eighteen or twenty in the embryo. Comparing the typical embryo-spindle as shown in Fig. 47 with a typical spindle from the female prothallium as shown in Fig. 48 , the difference in the number of the chromosomes in the two is very obvious. Hundreds of spindles in all stages in both the gametophyte and sporophyte were examined, and this difference was always very marked. The gametophyte-spindle had not only fewer chromosomes, but it was only about half as wide at the equator as the sporophyte-spindle. This is well illustrated in Figs. 47 and 48. Both these figures were drawn by the aid of the camera lucida and at the same magnification. As near as could be estimated there are nine or ten chromosomes in the gametophyte, and eighteen or twenty in the sporophyte of Cryptomeria.

The result of the first segmentation is shown in Fig. 50 ; two free nuclei are formed and they move towards the base of the archegonium. As they move downward both nuclei divide and we have four free nuclei, as shown in Fig. 5I. So many preparations showed this condition that $\mathrm{H} \mathrm{h}$ 
I am convinced that the first two divisions at least take place before the base of the archegonium is reached, although Arnoldi reports that the fusion-nucleus passes to the bottom of the archegonium before dividing. One preparation, as shown in Fig. 52, showed six free nuclei lying one behind the other. It seems to me very improbable that the uppermost of this row of nuclei originated at the base of the archegonium.

In his work on Taxodium, Coker ('03) makes special emphasis of the starch brought into the egg by the male cell. He reports that the protoplasm and starch of the male cell form a distinct layer around the eggnucleus. This later becomes separated from the egg and forms the greater part of the young embryo. In Cryptomeria a distinct zone of starch was observed surrounding each of the free nuclei of the pro-embryo. The quantity present, however, is very much greater than that brought in by the male cell, and I am therefore convinced that only a very small proportion of the starch present in the developing embryo comes from the male cell. Viewed in the light of what occurs in Sequoia (Lawson, '04), where all the starch of the male cell remains outside of the archegonium, and becomes disorganized in the pollen-tube, the point which Coker has raised is not of very great importance.

By the time the second division is completed, two or more of the free nuclei have settled in the base of the archegonium and they all prepare for the third division. Fig. 52 shows the manner in which the two lower nuclei are situated and the upper two have not yet reached the base. Each nucleus is surrounded by a dense zone of starch-granules. The starch is carried down with the nuclei and forms a very sharply differentiated region as shown in Figs. 53, 54, and 55 .

The third division results in the formation of eight nuclei, which are arranged in tiers as shown in Fig. 56 . In these latter stages it was impossible to see all the nuclei in a single section, but by studying the series, it was comparatively easy to distinguish eight nuclei. Immediately after the third division the continuous fibrils of the spindles persist, and present the appearance of radiating systems, which connect the daughternuclei with one another. In the first two divisions the entire spindles disappear immediately after the daughter-nuclei are organized, but after the third division the fibrils persist (Fig. 54 and 55), and the first cellmembranes of the embryo are formed between the nuclei. As shown in Fig. 55, these cell-walls of the upper tier are formed parallel with the long axis of the archegonium, and the cells thus formed are open on the inner or upper side.

The next division only concerns the upper tier of nuclei. The spindles are arranged at right angles to those of the preceding division, as shown in Fig. 56. A large number of preparations showed this stage, with the nuclei in all stages of mitosis. Cell-walls are now formed between the daughter- 
nuclei of the middle and upper tier, but not between the free nuclei of the upper tier. The result of this division is shown in Fig. 57. We have now in the pro-embryo two tiers of cells and one tier of free nuclei. The cytoplasm of the cells is very densely granular, containing an abundance of starch. It stains very deeply, and presents a very sharp contrast to the clear cytoplasm of the archegonium above, in which the tier of free nuclei lie embedded.

Arnoldi's ('01) account of the development of the pro-embryo in Cryptomeria is rather meagre, but the four stages which he figures agree with my own observations. With the exception of the first two divisions, Coker's ('03) account of the pro-embryo of Taxodium agrees very closely with that here given for Cryptomeria.

The next stage in the development of the embryo is the elongation of the middle tier of cells. The development of the suspensors from these cells was followed very closely ; many preparations showing all the essential stages in this formation. Fig. $5^{8}$ shows that cells of the middle tier have become much longer than the original archegonium, and as they grow, they carry the lower tier of cells downward through the tissue of the prothallium. At first the suspensors elongate in a straight line, but, as shown in Fig. 58 , they soon become more or less curved. As they increase in length, this curvature becomes more marked, until they assume a distinct winding form. This curvature and winding in and out of the suspensors may be explained on the assumption that the rate of growth of the cells is very much greater than the rate with which they can be forced through the solid cellular tissue of the prothallium. As they wind in and out in all directions, it is impossible to observe their exact length or direction of growth in a single section. Fig. 59 represents a longitudinal section of the older suspensors with an embryo at the tip. It will be seen that a portion of the suspensors has been cut away in sectioning on account of the direction of their growth. It will also be observed that the suspensors are enormously long, and if they were stretched out their full length they would reach over half the length of the prothallium.

In the stages older than that shown in Fig. 59, it was impossible to trace back the suspensors to their point of origin. With so many suspensors from the various archegonia, all growing together and winding in and out in all directions, the upper region of the prothallium showed nothing but a confused tangle of long suspensor cells.

It was very difficult to estimate accurately the number of embryos developed from one archegonium; my preparations showed a marked variation in this respect. The suspensors from several archegonia were sometimes found growing downward close together, and in such cases it was impossible to say definitely whether a series of suspensors came from one or more archegonia. By the time the suspensors reached the stage 
shown in Fig. 59, the tips of the suspensors usually separated from each other. There were generally one or two embryo-cells at the end of each suspensor. The two cells at the tip were merely the two-celled stage of the embryo proper. In no case was I able to find more than one embryo developed from a single suspensor as Coker ('03) has recently reported for Taxodium. One embryo was generally developed from one suspensor, but very frequently a single embryo was found at the united tips of two or sometimes three suspensors.

In the later stages, distinct embryonal tubes are developed from the cells nearest the suspensors, in much the same fashion as they do in Taxodium (Coker, '03). They are, however, not as numerous or as long as in Taxodium.

While differing in certain minor details, the development of the embryo of Cryptomeria and Taxodium is very similar. To Sequoia, where there are no free nuclei formed in the pro-embryo, Cryptomeria bears no resemblance whatever.

\section{SUMMARY.}

The reduction-division which leads to the formation of the tetrads takes place during the latter part of October, although pollination does not take place until March of the following spring. At the time of pollination the microspore contains a tube-cell and a generative cell. Cells or nuclei representing the vegetative tissue of the male gametophyte are not formed.

There are usually four or five microspores deposited on the nucellus at the base of the micropyle. These all germinate and produce pollen-tubes, which penetrate the nucellar tissue at the apex. At the time of penetration the generative nucleus divides, so that the young pollen-tube contains the tube-, stalk-, and body-nuclei.

The body-nucleus very soon enlarges and becomes surrounded by a dense zone of cytoplasm and starch-grains. A membrane is formed at the periphery of this zone. The pollen-tube now contains one large cell and two free nuclei.

After the tip of the pollen-tube has reached the depression above the archegonium-complex, the body-cell divides and gives rise to two male cells. The two male cells when mature are spherical in form, of equal size, and both are functional. They enter separate archegonia.

There are three or four macrospore-mother-cells differentiated in the nucellus at a point just a little above the insertion of the integument. Each mother-cell divides twice, and there are consequently from twelve to sixteen macrospores formed.

Only one of the macrospores germinates and develops into the female 
gametophyte. No distinct tapetum is present. Upon germination the nucleus of the macrospore divides and the spore enlarges. Free nuclear division now proceeds at a rapid rate, and the young prothallium elongates in the direction of the chalaza. There are now several vacuoles present, and the nuclei are distributed along the intervening strands of cytoplasm. The vacuoles enlarge and eventually flow together. The very large central vacuole increases enormously, and forces the cytoplasm to the wall. The prothallium now consists of a large central vacuole and a parietal layer of cytoplasm, along which the free nuclei are distributed at more or less regular intervals.

As the prothallium increases in size, the parietal layer of cytoplasm becomes thicker and the free nuclei divide. Between the daughter-nuclei thus organized delicate membranes are formed. The structures thus formed are the first cells of the prothallium, and they are open on the inner side. The nuclei at this time always occupy a position at the periphery of the cytoplasm on the side exposed to the sap of the vacuole. These primary prothallial cells now elongate and grow inward towards the centre of the vacuole. During this growth free nuclear division proceeds, and numerous cross-walls are formed, but the cells nearest the vacuole are always open on the inner side.

The primary prothallial cells soon become multinucleate, and by this inward growth eventually close up the space occupied by the sap of the vacuole. The membranes of these primary cells are very delicate and incomplete, they do not extend across the prothallium, and eventually take no part whatever in the formation of permanent cell-walls of the cellular endosperm.

The cell-walls are formed as a result of a peculiar method of free cell-formation. The manner in which these walls are formed is unlike anything that has so far been reported for endosperm-formation. Hundreds of the free nuclei divide about the same time. When the daughter-nuclei are formed at the poles of the spindle, the kinoplasmic fibrils stretching between them increase in number and curve outward on all sides. No cell-plate is formed between the daughter-nuclei. The fibrils continue to increase in number, and curve out still further. This process continues until both daughter-nuclei are completely surrounded by a sheath of fibrils. The fibrils are all at the periphery of the nearly spherical structures thus formed. By fusion together laterally, the fibrils are gradually converted into a membrane which completely encloses the two nuclei. This process of free cell-formation goes on throughout the whole of the prothallium except in the region of the archegonial initials. As hundreds of these structures are formed they become crowded, and the walls become flat where they press upon one another. Through this pressure the neighbouring membranes fuse together, and this gives the appearance of ordinary 
cellular tissue. The prothallium thus passes through a stage when the majority of its cells are binucleate. After this binucleate cellular tissue has been organized, nuclear division proceeds in the usual way, and cell-plates are formed between the daughter-nuclei.

The archegonial initials make their appearance just before the prothallial tissue is thoroughly organized. They are nearly always peripherical cells. There are four neck-cells, and a ventral canal-nucleus is cut off before fertilization. The archegonia are arranged as in the Cupresseae, that is, in a single group at the apex of the prothallium. They are surrounded by a common layer of jacket-cells, but these latter are sometimes found between the archegonia. The jacket-cells are multinucleate, and their characters suggest that they may be sterile archegonia.

A single male cell enters the archegonium, and after the wall surrounding it breaks down the sex-nuclei fuse. The first segmentation-spindle is organized in the centre of the archegonium just about the place where the fusion of the sex-nuclei occurred. After the second division the four free nuclei pass to the base of the archegonium and undergo another division, but meantime the nuclei have been arranged in two tiers. Walls are now formed between the nuclei, and then the nuclei of the upper tier divide. The walls formed between these latter are at right angles to the long axis of the archegonium, but the upper tier forms no membranes between its nuclei. The embryo now consists of two tiers of cells and one tier of free nuclei. The middle tier develops into long, tortuous suspensors, which carry down the embryo cells at their tips. There may be one or several embryos developed from a single archegonium.

As near as could be estimated, there are nine or ten chromosomes in the nucleus of the gametophyte, and eighteen or twenty in the sporophyte.

The gametophytes and embryo of Cryptomeria are distinctly of the Cupresseae type.

\section{LiteratuRE Cited.}

ARNoldi, W. ('00): Beiträge zur Morphologie der Gymnospermen: III, Embryogenie von Cephalotoxus Fortuni. Flora, 1xxxvii, p. 46, 1900.

('00): Beiträge zur Morphologie einiger Gymnospermen : I. Die Entwicklung des Endosperms bei Sequoia sempervirens. Bull. Soc. Imp. Nat. Moscou, I900.

('00) : Beiträge zur Morphologie und Entwicklungsgeschichte einiger Gymnospermen :

II. Ueber die Corpuscula und Pollenschläuche bei Sequoia sempervirens. Bull. Soc. Imp. Nat. Moscou, I900.

('01): Beiträge zur Morphologie einiger Gymnospermen: V. Weitere Untersuchungen über die Embryologie in der Familie der Sequoiaceen. Bull. Soc. Imp. Nat, Moscou, I 901 . 
Belajeff, W. ('93): Zur Lehre von dem Pollenschlauche der Gymnospermen. Ber. der Deutsch. Bot. Gesell., ii, p. 196.

Blackman, V. H. ('98): On the Cytological Features of Fertilization and Related Phenomena in Pinus silvestris, L. Phil. Trans. Roy. Soc., cxc, p. 395.

CAMpbell, D. H. ('02): A University Textbook of Botany. New York, 1902.

Chamberlain, C. J. ('99): Oogenesis in Pinus Laricio. Bot. Gaz., xxvii, p. 268.

Coker, W. C. ('03): The Gametophytes and Embryo of Taxodium. Bot. Gaz., xxxvi, pp. I-27 and II $4-I_{4}$.

('02): Notes on the Gametophytes and Embryo of Podocarpus. Bot. Gaz., xxxiii, p. 89.

Coulter, J. M., and Chamberlain, J. C. ('01): Morphology of Spermatophytes, Part I. New York, 1901 .

Dixon, H. N. ('94) : Fertilization in Pinus silvestris. Ann. Bot., viii, p. 2 I.

Ferguson, M. C. ('01): The Development of the Pollen-tube and the Division of the Generative Nucleus in certain species of Pinus. Ann. Bot., xv, p. 193.

('01): The Development of the Egg and Fertilization in Pinus Strobus. Ann. Bot., xv, p. 435 .

Goroschankin, J. ('83): Zur Kenntniss der Corpuscula bei den Gymnospermen. Bot. Zeit., xli, p. 825 .

HARPER ('97): Kerntheilung und freie Zellbildung im Ascus. Jahrb. f. wiss. Bot., Bd. xxx, I897. ('00): Sexual Reproduction in Pyronema confuens and the Morphology of the Ascocarp. Ann. Bot., xiv, no. lv.

Hirasé, S. ('95): Études sur la fécondation et l'embryogénie du Ginkgo biloba. Jour. Coll. Sci. Imp. Univ. Tokyo, viii, p. 307 .

Ikeno, S. ('96): Das Spermatozoid von Cycas revoluta. Bot. Mag. Tokyo, x, p. $3^{67}$.

JÄGER, L. ('99) : Beiträge zur Kenntniss der Endospermbildung und zur Embryologie von Taxus baccata. Flora, lxxxvi, p. $24 \mathrm{I}$.

LAND, W. J. G. ('02): A Morphological Study of Thuja. Bot. Gaz., xxxvi, p. 249.

Lawson, A. A. ('04): The Gametophytes, Archegonia, Fertilization and Embryo of Sequoia sempervirens. Ann. Bot., xviii, no. 1xix.

JuEL, H. O. ('00) : Beiträge zur Kenntniss der Tetradentheilung. Jahrb. f. wiss. Bot., xxxv, p. 626, I900.

Mryake, K. ('03): On the Development of the Sexual Organs and Fertilization of Picea excelsa. Ann. Bot., xvii, p. 66.

MUrrill, W. A. ('00): The Development of the Archegonium and Fertilization in the Hemlock Spruce (Tsuga Canadensis). Ann. Bot., xiv, p. $5^{83}$.

Shaw, W. R. ('96): Contribution to the Life-history of Sequoia sempervirens. Bot. Gaz., xxi, p. $33^{2}$.

Sokolowa, Mlle C. ('90): Naissance de l'endosperme dans le sac embryonnaire de quelques Gymnospermes. Bull. Soc. Imp. Nat. Moscou, I89o (I89I), p. 446.

Strasburger, E. ('72): Die Coniferen und Gnetaceen, I $877^{2}$.

('79): Die Angiospermen und die Gymnospermen, 1879.

('84): Neue Untersuchungen über die Befruchtungsvorgänge bei den Phanerogamen als Grundlage fur eine Theorie der Zeugung. Jena, 1884 .

Webber, H. J. ('97): Peculiar Structure in the Pollen-tube of Zamia. Bot. Gaz., xxiii, p. 453. ('97): The Development of the Antherozoids of Zamia. Bot. Gaz., xxiv, p. I6.

('97): Notes on the Fecundation of Samia and the Pollen-tube Apparatus of Ginkgo. Bot. Gaz., xxiv, p. 225.

('01): Spermatogenesis and Fecundation of Zamia. U.S. Dept. Agri. Bur. of Plant Industry. Bull., ii, $190 \mathrm{I}$.

WoycickI, Z. ('99): Fertilization in the Coniferae. Warsaw, 1899. Reviewed in Jour. Roy. Micro. Soc., p. 482 , 1900. 


\title{
EXPLANATION OF FIGURES IN PLATES XXVII-XXX.
}

\author{
Illustrating Dr. Lawson's paper on Cryptomeria.
}

All the figures were drawn with the aid of the camera lucida. The following oculars and objectives were used :-

Figs. I, 2, 3, 4, 5, 6, I 2, I3, I 4, 35, 4I, 42, 45, Zeiss oc. I, obj. oil imm. $\frac{1}{12}$.

Fig. 8, Zeiss oc. 3 , obj. 7 .

Figs. 9, Io, 11, I 5, 39, 40, 59, Zeiss oc. 2, obj. 3 .

Figs. 7, 16, 17, 18, Zeiss oc. 3 , obj. 3 .

Figs. I9, 20, 21 22, 25, 26, 27, 28, 29, 30, 31, 32, Zeiss oc. 3, obj, oil imm. $\frac{1}{12}$.

Figs. ${ }^{2} 3,34,36,37,38,43,44,49,5^{\circ}, 5^{\mathrm{I}}, 5^{2}, 53,54,55,56,57,58$, Zeiss oc. 4 , obj. 7 .

Figs. 24,33 , Zeiss oc. 5. obj. 7 .

Figs. $46,47,48$, Zeiss oc, 5 , obj. oil imm, $\frac{1}{12}$.

Fig. I. A cross-section of a microspore soon after the separation of the tetrads. Nov. I, I903. $\times 1000$.

Fig. 2. A microspore showing the hook-like projection. Drawn from living spore. Dec. I, 1903. $\times$ 1000.

Fig. 3. A section of a microspore soon after it reaches the apex of the nucellus. March 7 , 1903. $\times 1000$.

Fig. 4. The body-cell $t$., stalk-nucleus s.n., and tube-nucleus $t . n$. as they are situated at the tip of the pollen-tube. June 2, $1903 . \times 1000$.

Fig. 5. The body-cell undergoing division with the stalk-nucleus situated just below it. June 9, $1903 . \times 1000$.

Fig. 6. The two male cells just separating from each other. June 5, I903. $\times 1000$.

Fig. 7. A longitudinal section of the apex of the nucellus, showing at least four pollen-tubes penetrating the nucellar tissue. May 26, $1902 . \times 150$.

Fig. 8. A longitudinal section of a pollen-tube with the tip just about to discharge its contents in the depression above the archegonium-complex. June 2, I902. $\times 300$.

Fig. 9. A longitudinal section of a young megasporangium and integument, showing the method of closing of the micropyle. March $\uparrow, 1903 . \times$ I 70.

Fig. 10. A longitudinal section of two young megasporangia within a single integument. March $7,1903 . \times 170$.

Fig. Ir. A longitudinal section of a megasporangium showing the position of the sporogenous cells. March 7, $1903 . \times$ I 70.

Fig. 12. From a longitudinal section of a megasporangium showing four megaspore-mothercells. March $7,1903 . \times 1000$.

Fig. 13. The spindle of the reduction-division of the megaspore-mother-cell. The daughternuclei are already organized at the poles. March $7,1903 . \times 1000$.

Fig. 14. A longitudinal section showing at least fourteen megaspores. The large centrally situated spore is probably the only one that germinates. April 6, 1903. $\times 1000$.

Fig. I5. A longitudinal section of the nucellus, showing a large single embryo-sac with numerous free nuclei. May I 2, 1902. $\times$ I 70.

Fig. 16. A longitudinal section of a young female prothallium, showing the large central vacuole and the parietal layer of cytoplasm, in which numerous free nuclei are imbedded at more or less regular intervals. May 26, $1902 . \times 150$.

Fig. 17. The same at a later stage. The free nuclei in the parietal layer of cytoplasm have divided and delicate membranes formed between them. The primary cells thus organized are open on the side towards the vacuole. The nuclei are arranged at the periphery of the cytoplasm and the latter is exposed to the sap of the vacuole. May 29, $1903 . \quad \times 150$.

Fig. I8. The same at a little older stage, showing the inward growth of the primary prothallial 


\section{Embryo of Cryptomeria Faponica.}

cells. Numerous cross-walls have already formed, but the cells that extend as far as the vacuole are still open on the inner side. The nuclei in these cells still retain their position at the periphery of the cytoplasm exposed to the fluid of the vacuole. May 26, I902. $\times$ I50.

Fig. I9. A longitudinal section of the parietal layer of cytoplasm from the stage shown in Fig. 16, but at a much higher magnificatiou. May 26, 1903. $\times$ I500.

Fig. 20. The same at a little later stage, where the nuclei have just divided. Delicate membranes are formed between the daughter-nuclei, and the primary cells or 'alveoli' are thus organized. They are open on the side exposed to the vacuole. May 29, I903. $\times$ I 500.

Fig. $2 \mathrm{I}$. The same at a later stage, showing that cross-walls are formed at this early stage. May 26, I902. $\times$ I 500.

Fig. 22. A section of the parietal layer of cytoplasm taken parallel with the inner exposed surface, showing how the walls are formed separating the nuclei. May 29, I903. $\times$ I500.

Fig. 23. A longitudinal section of the upper end of the prothallium, showing the multinucleate nature of the primary prothallial cells, and also that the walls of these cells are incomplete. May 26, 1902 . $\times 350$.

Fig. 24. A portion of a longitudinal section of the prothallium, showing the process of free cellformation. May 29, 1903, $\times 480$.

Fig. 25. One of the free nuclei undergoing division and preparing for free cell-formation. May 29, 1903. $\times$ I 500.

Fig. 26. The same at a later stage. May 29, 1903. $\times$ I $_{5} 00$.

Fig. 27. A still later stage of the same, showing the formation of the kinoplasmic fibrils between the daughter-nuclei. May 29, I903. $\times$ I 500.

Fig. 28. The same, showing how the kinoplasmic fibrils curve outward. May 29, I903. $\times \mathbf{I 5 0 0 .}$

Fig. 29. The same at a little later stage. May 29, 1903. $\times 1_{5} 00$.

Fig. 30. The two daughter-nuclei completely enclosed by the kinoplasmic fibrils. May 29, I903. $\times$ I 500 .

Fig. 3I. A section taken at right angles to the long axis of the spindle of the stage shown in Fig. 30. The cross-sections of the kinoplasmic fibrils appear as small dots. By fusing together laterally, these fibrils form a membrane. May 29, 1903. $\times 1500$.

Fig. 32. A section taken same as in Fig. $3 \mathrm{I}$. The two nuclei cannot be seen at the same focus. May 29, I903. $\times$ I 500.

Fig. 33. A portion of the prothallium soon after free cell-formation. The membrane formed by the lateral fusion of the kinoplasmic fibrils encloses both daughter-nuclei, so at this time the cells of the prothallium are binucleate. May 29, I903. $\times 480$.

Fig. 34. A longitudinal section of the apex of the young prothallium, showing a group of archegonial initials. May 29, 1903. $\times 350$.

Fig. 35. A longitudinal section of the upper portion of an archegonium, showing the division of the neck-cell. The membrane between the two nuclei is not yet formed. June 5, I903. $\times 1000$.

Fig. 36. A longitudinal section of an archegonium showing the large egg-nucleus $e_{\text {., }}$ and the small ventral canal-nucleus v.c. June $\mathrm{I}, \mathrm{I} 90_{3} . \quad \times 35^{\circ}$.

Fig. 37. A longitudinal section of a typical mature archegonium ready for fertilization. June I, I903. $\times 35^{\circ}$.

Fig. $3^{8}$. A cross-section through the necks of the archegonia, showing four distinct neck-cells in each neck, and also the clefts between these cells. June 2, I902 $\times 350$.

Fig. 39. A longitudinal section of the upper portion of the prothallium, showing the typical way in which the archegonia are grouped. The jacket-cells surround the entire group, but occasionally run up between the archegonia. June I, I903. $\times$ I 70.

Fig. 40. A cross-section of the prothallium through the region of the nuclei of the archegonia, showing the way in which the latter are grouped. There are twelve archegonia shown in the section. June 7, I903. $\times$ I70.

Fig. 4I. A section of the central nucleus preparing for the division which gives rise to the ventral canal-nucleus. June 2, I902. $\times$ I000.

Fig. 42. A group of jacket-cells, showing their multinucleate character. June 9, I903. $\times 1000$.

Fig. 43. An archegonium showing the male cell just after it has penetrated. The latter fills the entire upper portion of the archegonium and the membrane surrounding it is still intact. June I, 1903. $\times 350$. 


\section{Lawson.-The Gametophytes of Cryptomeria Faponica.}

Fig. 44. An archegonium showing the fusion of the male and female nuclei. The nuclear membrane between the two persists for some time. June $5,1903 . \times 35^{\circ}$.

Fig. 45. A later stage of the same, showing that the female nucleus almost completely envelops the male before the membrane between them breaks down. The structure of the chromatin of the two nuclei are very similar at this time. June I, I903. $\times 1000$.

Fig. 46. The first segmentation-spindle surrounded by a dense zone of starch-granules. June 9 , 1903. $\times 2000$.

Fig. 47. A spindle of the second division of the pro-embryo, showing the large number of long V-shaped chromosomes on their way to the poles. June 9, I903. $\times 2000$.

Fig. 48. A spindle of the division of one of the free nuclei of the endosperm, showing that there is clearly half the number of chromosomes in the gametophyte that there is in the sporophyte as shown in Fig. 47. May 29, $1903 . \quad \times 2000$.

Fig. 49. An archegonium showing the fusion-nucleus surrounded by a zone of starch-granules. June 9, 1903. $\times 350$.

Fig. 50. An archegonium showing two free nuclei; the result of the first division of the fusionnucleus. June $9,1903 . \times 35^{\circ}$.

Fig. $5^{1}$. An archegonium showing the result of the second division after fertilization. The pro-embryo now consists of four free nuclei. June $9,1903 . \times 35^{\circ}$.

Fig. 52. An archegoninm showing six free nuclei in the pro-embryo. June $9,1903 . \times 350$.

Fig. 53. An archegonium showing four nuclei of the pro-embryo. Two of the nuclei have settled at the base of the archegonium. The zone of starch is carried to the base with the nuclei. June $9,1903 . \times 35^{\circ}$.

Fig. 54. The base of an archegonium showing four free nuclei lying in a sharply differentiated starch area. Kinoplasmic fibrils radiate out from the nuclei preparatory to forming the membranes between the latter. June $9,1903 . \times 35^{\circ}$.

Fig. 55. A later stage than Fig. 54, showing that the first membranes between the free nuclei of the pro-embryo are formed parallel to the long axis of the archegonium. June 9, $1903 . \quad \times 350$.

Fig. 56. A later stage of the same, showing that the second series of membranes is formed at right angles to the long axis of the archegonium. June $9,1903 . \quad \times 35^{\circ}$.

Fig. 57. A later stage of the same, showing that the embryo now consists of two tiers of welldefined cells and one tier of free nuclei. June $29,1903 . \times 35$.

Fig. 58. A later stage, showing that the middle tier of cells has developed into a series of long suspensors, which carry the lower tier, or embryo proper, down through the endosperm. June 7 , $1903 . \times 35^{\circ}$.

Fig. 59. A later stage, showing the long tortuous suspensors with the embryo at the tip. June $25,1902 . \times 170$. 
Annals of Botany.

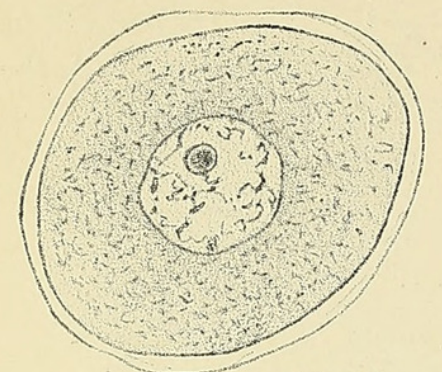

Fig.1

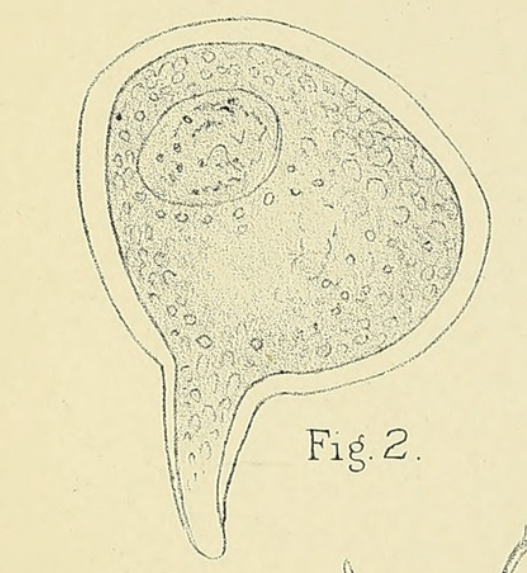

Fig. 3
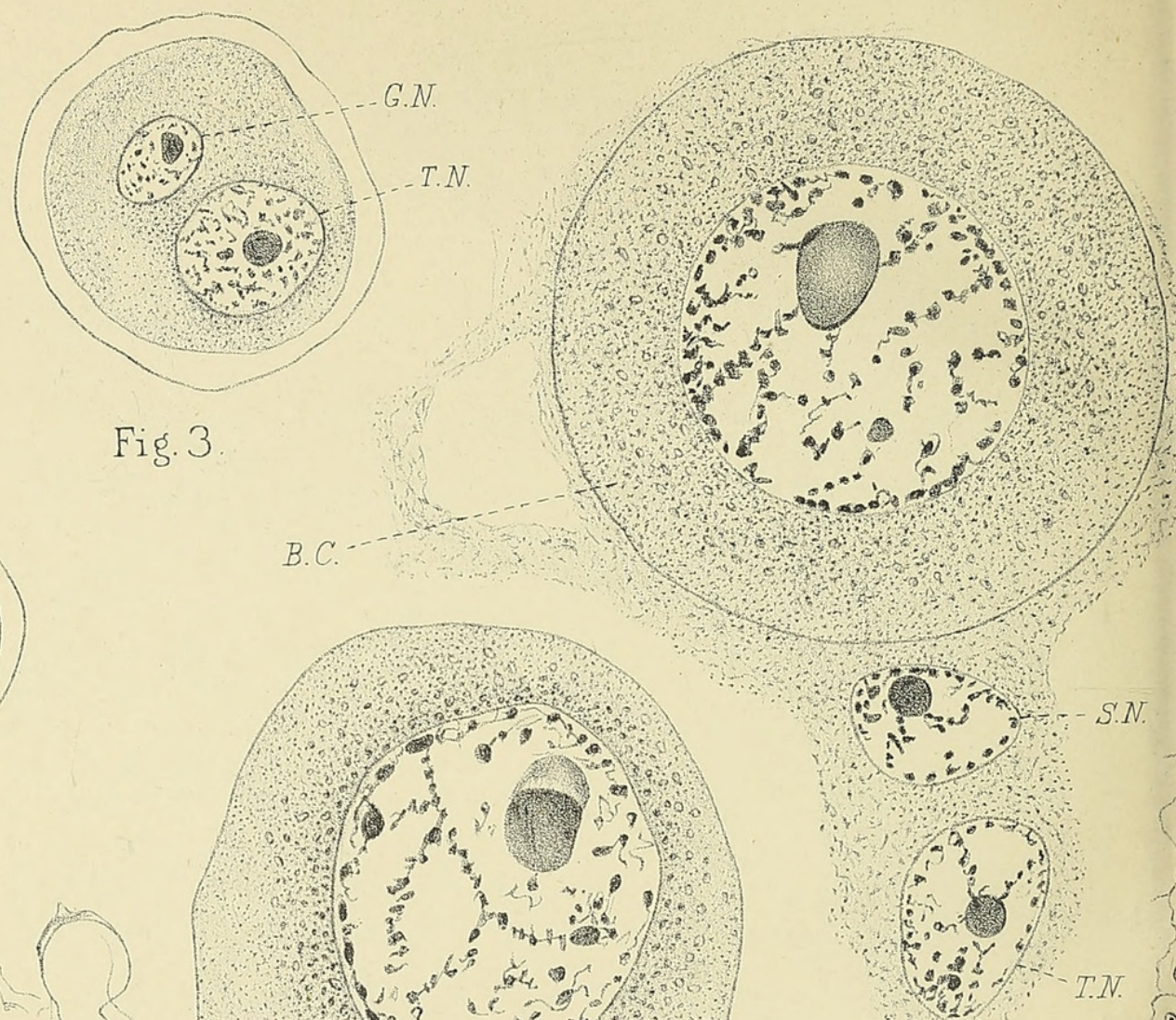

(0)

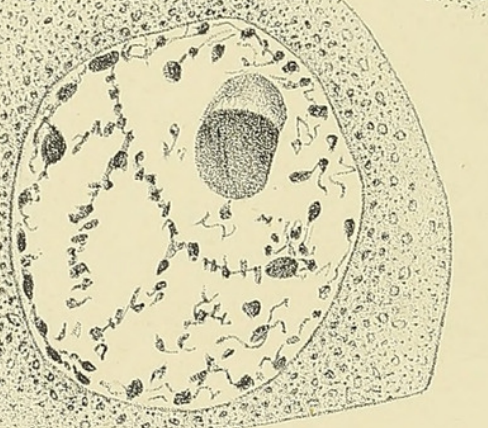

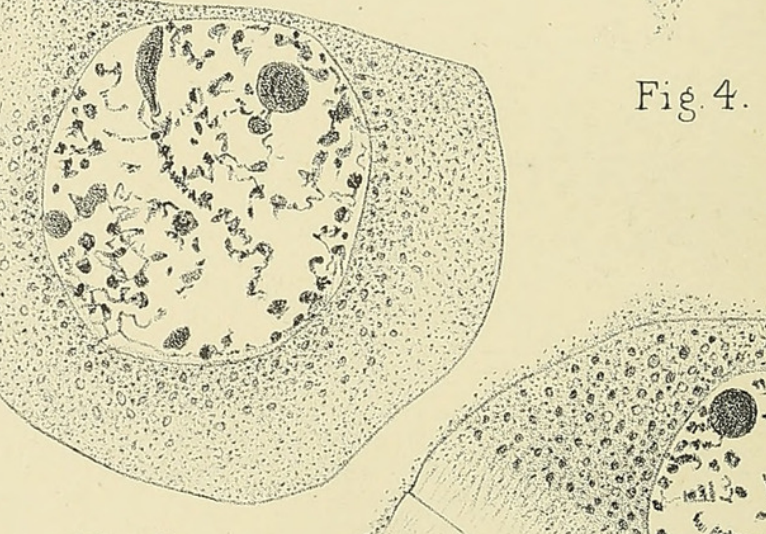

(2) \{

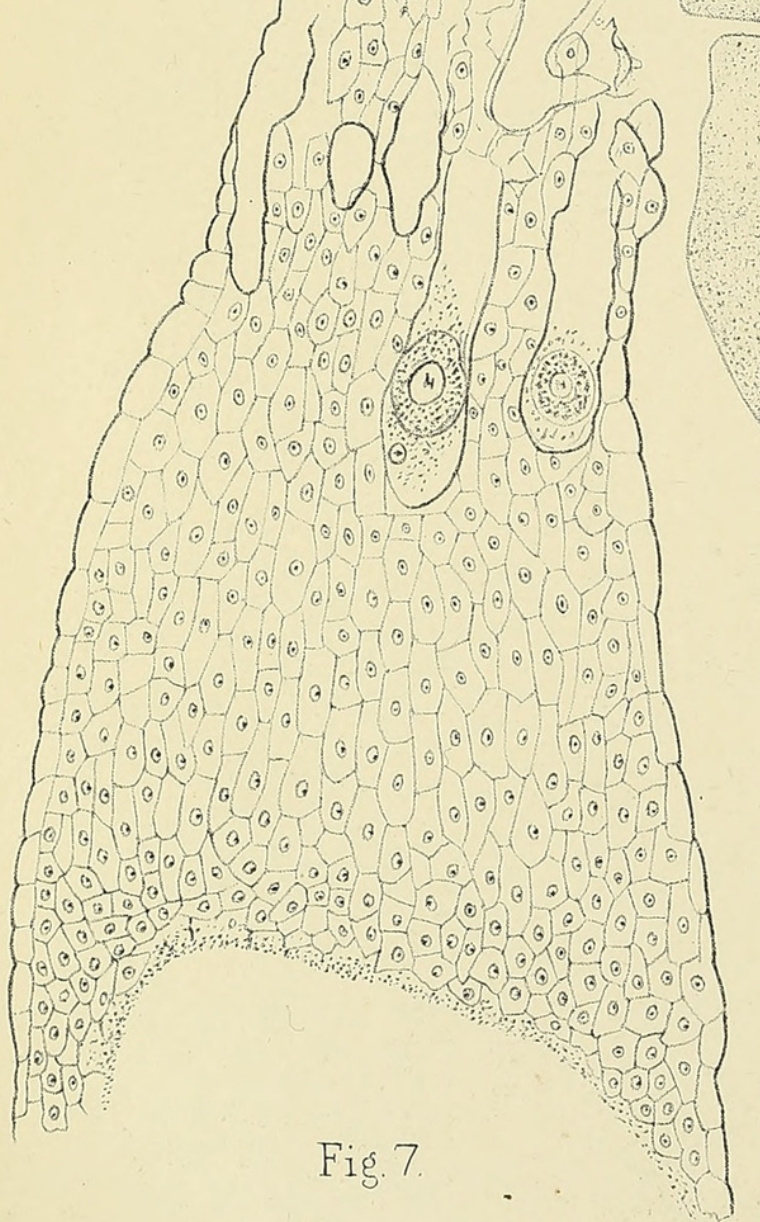

Fig. 6.

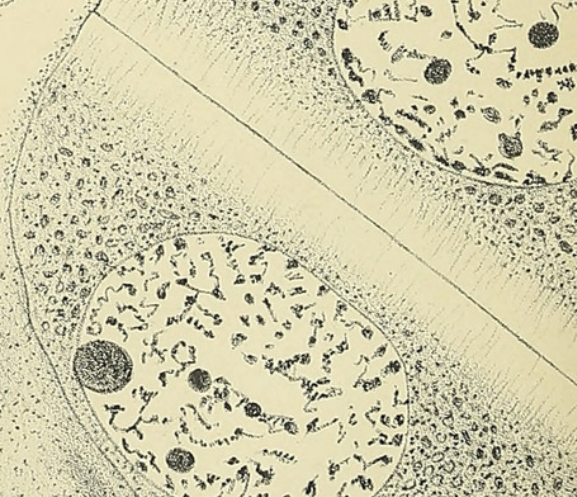

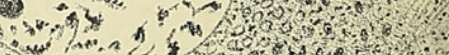
(3)

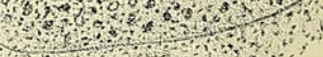

Fig. 5 


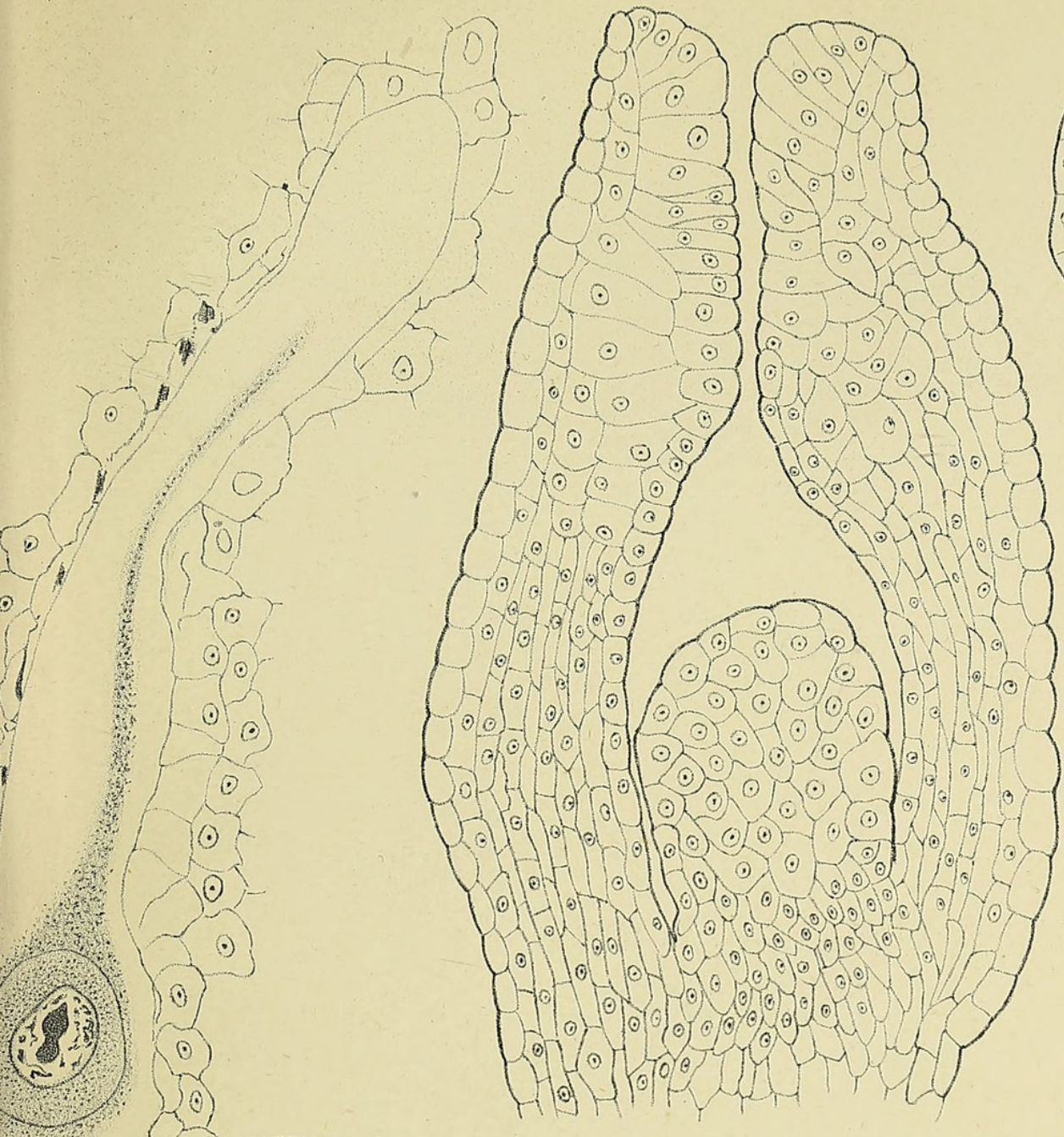

Fig. 9.

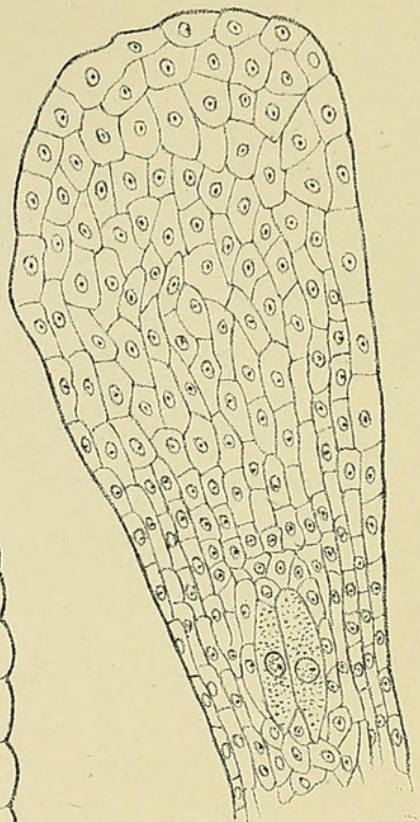

Fig.l1.

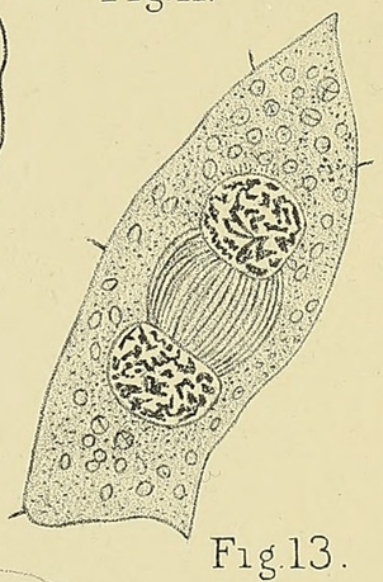

Fig. 8

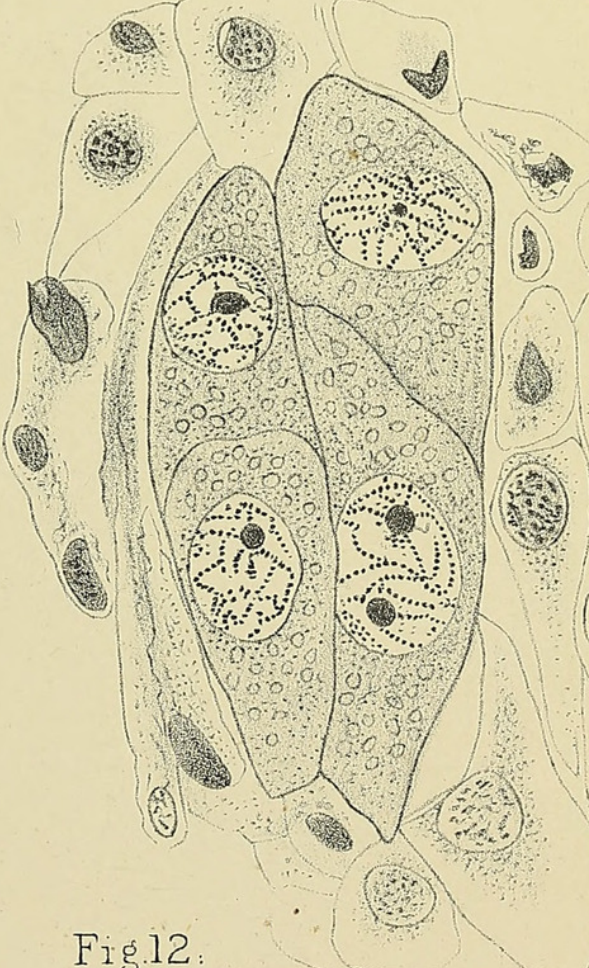

(2:0)

Fig. 10.

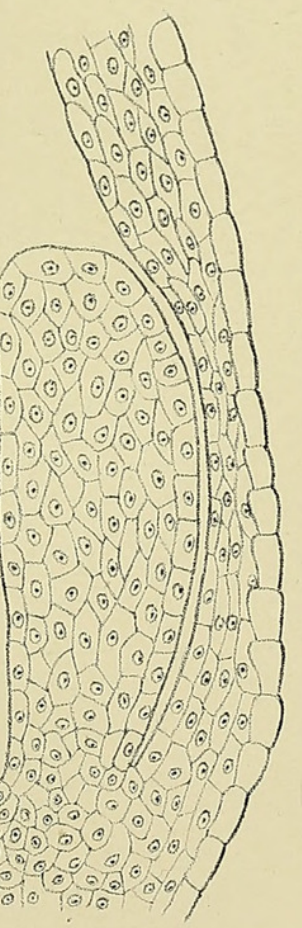

Fig.12 

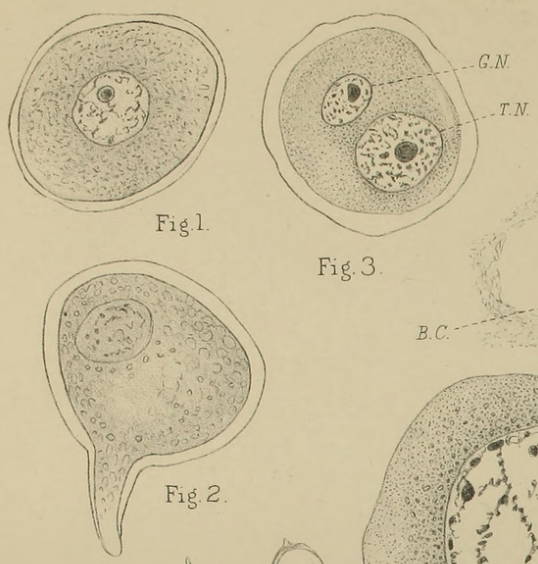

Fig. 3

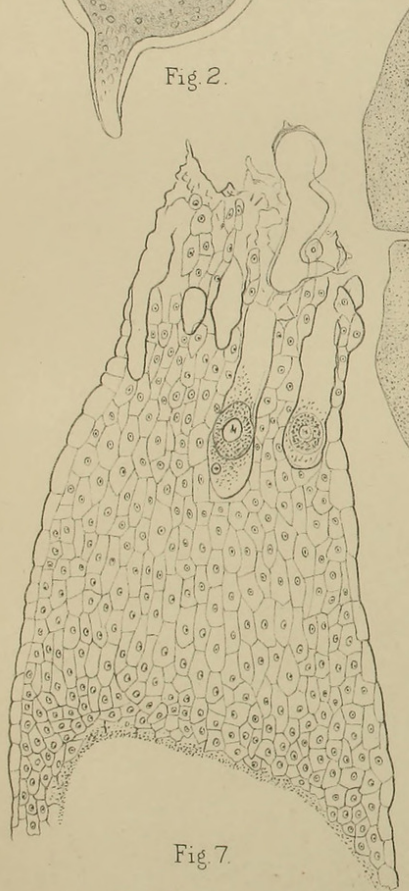

Fig̨. 7
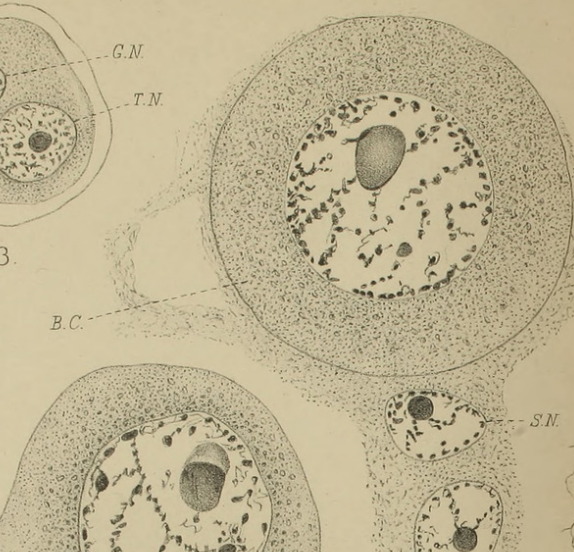

$\Rightarrow 6 \%$ mis

(1)
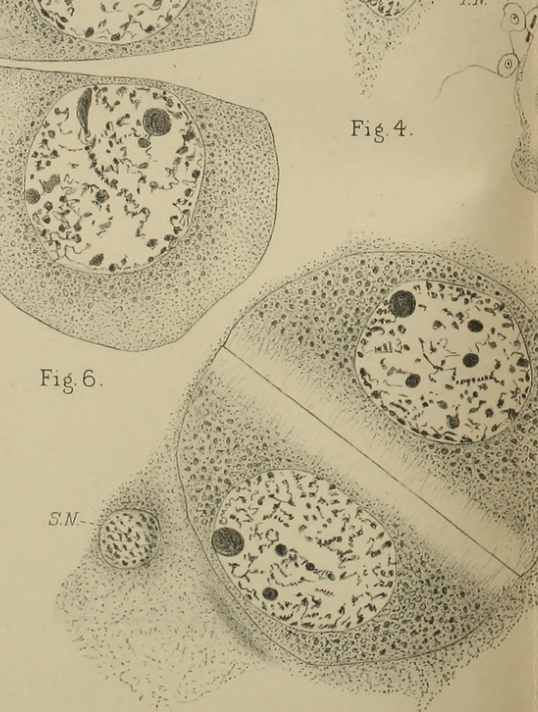

Fiǵ. 5.
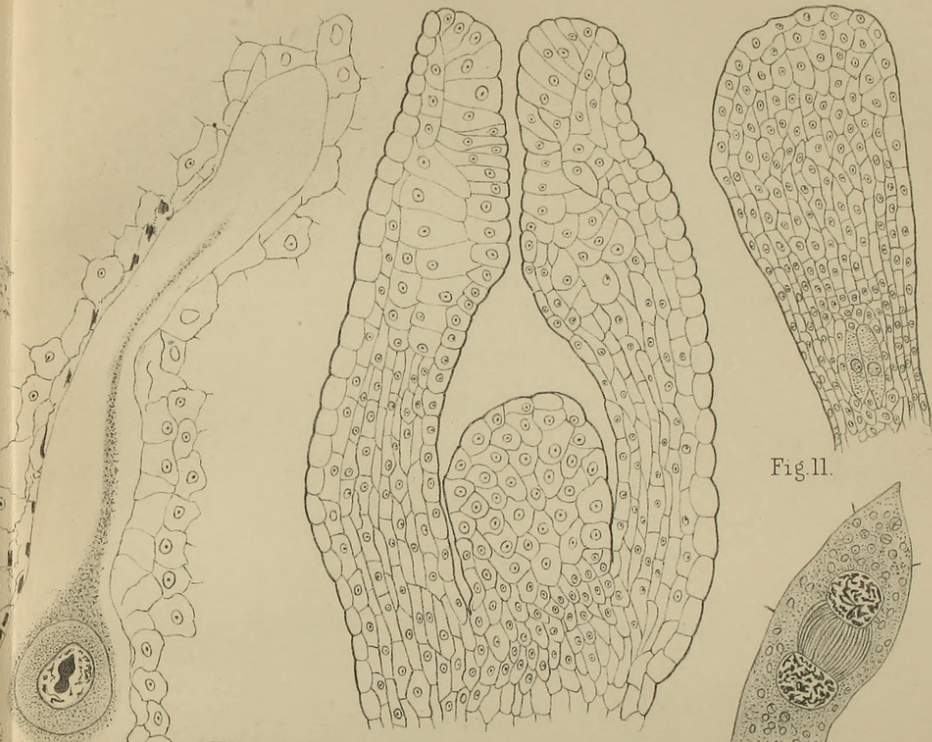

Fig.11

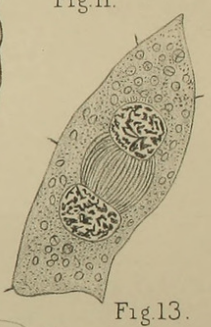

$$
\text { Fis̆. } 8 .
$$
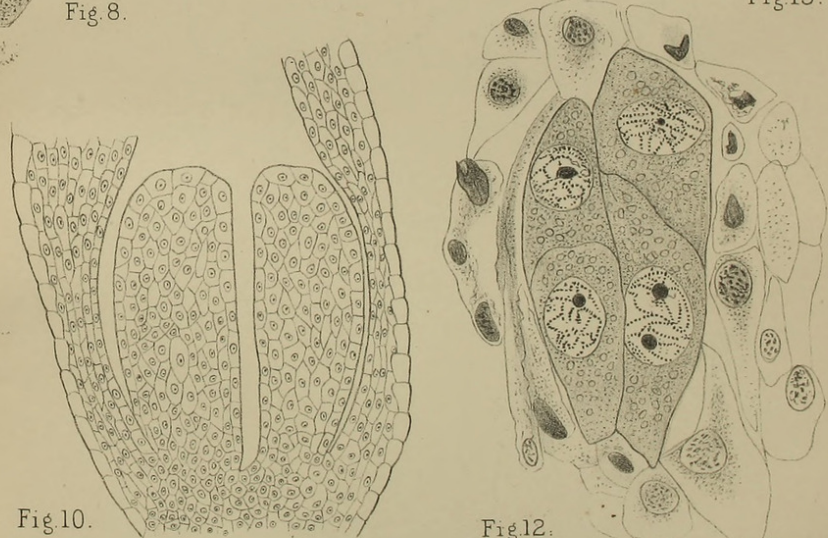

Fiø.12 
Annals of Botany.

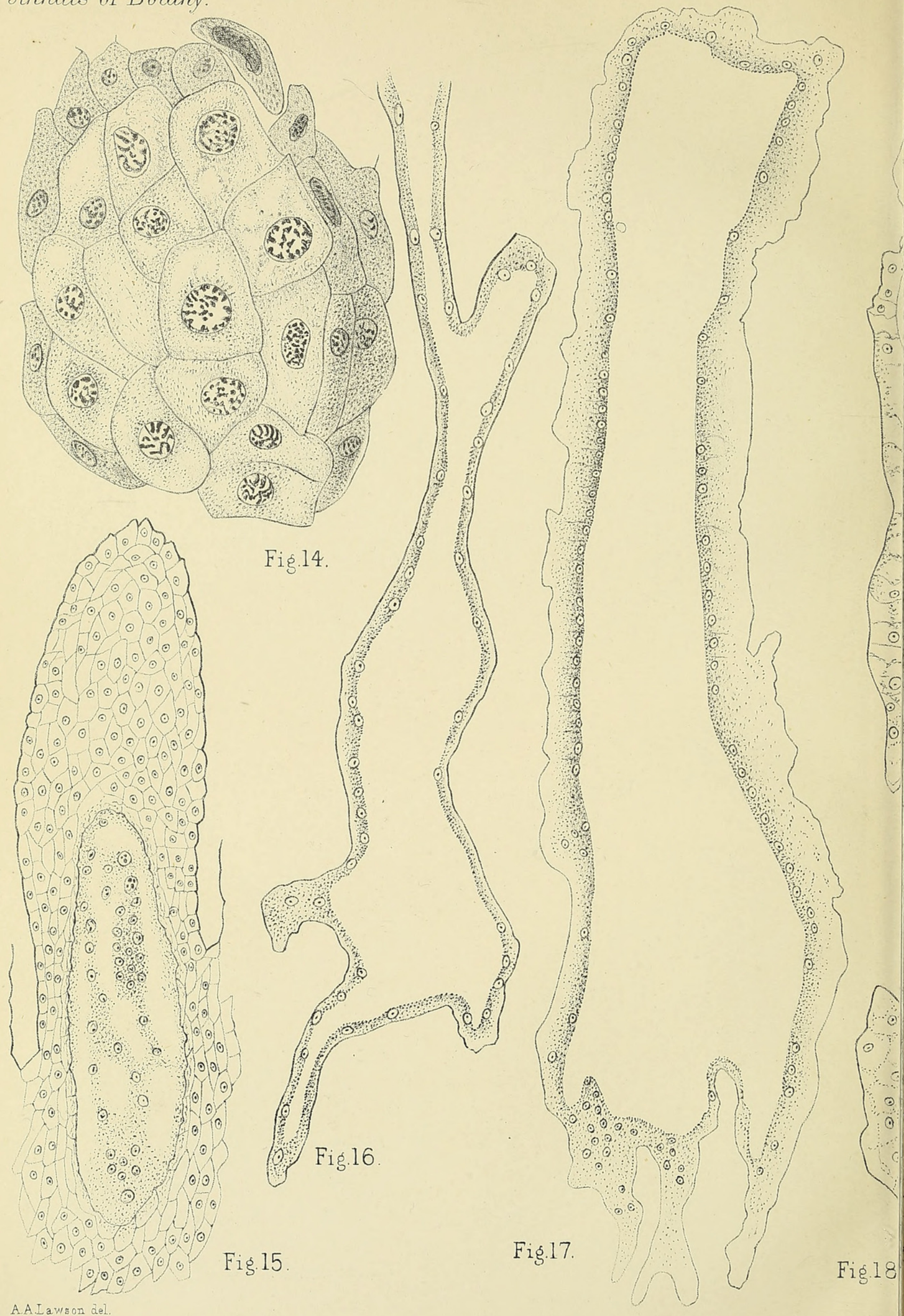




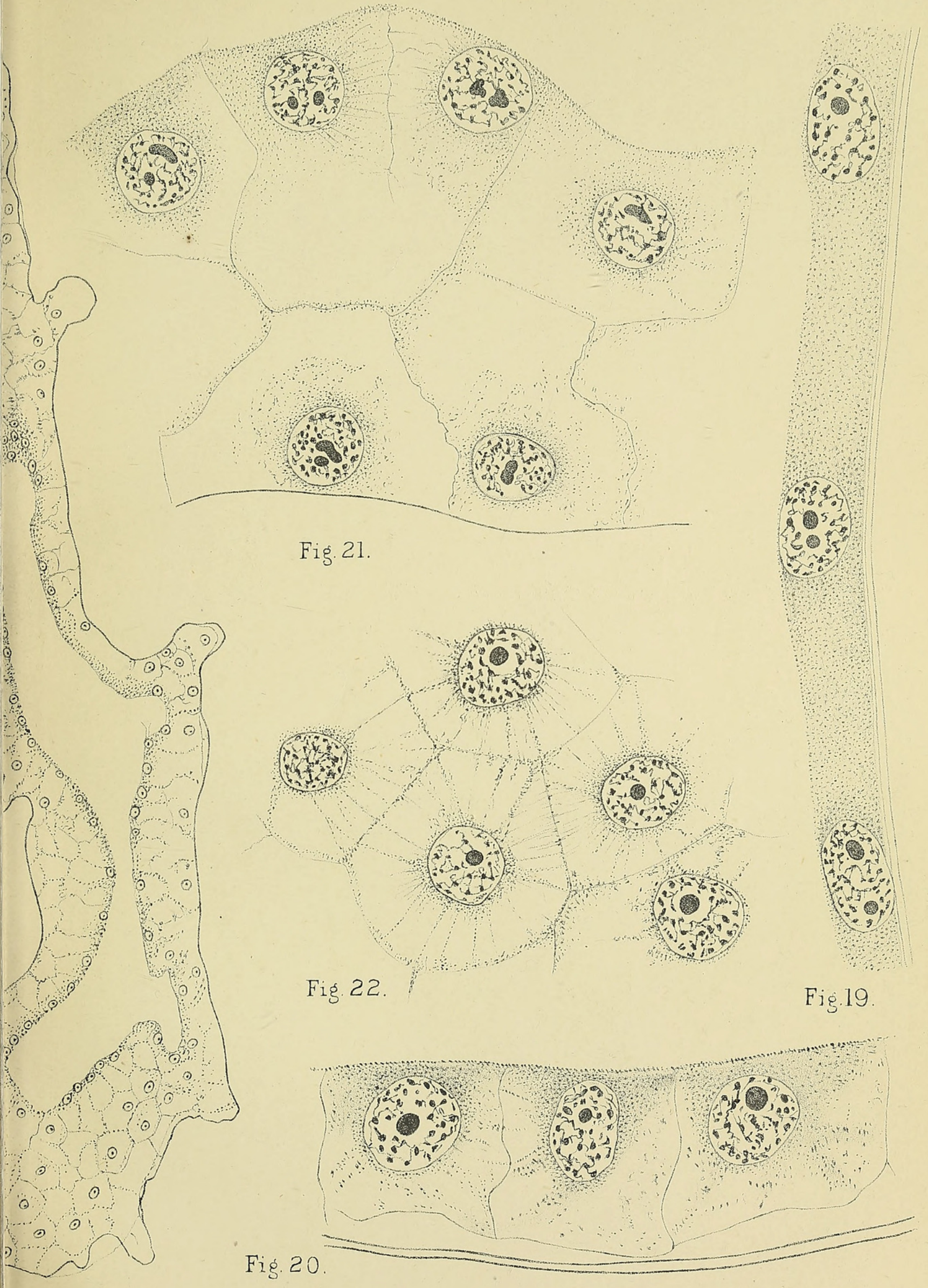




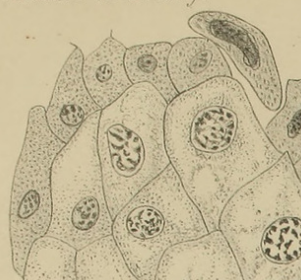

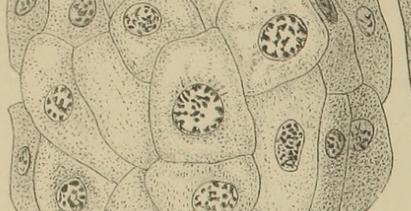

$(69)\left(\begin{array}{ll}63 \\ (6)\end{array}\right)$
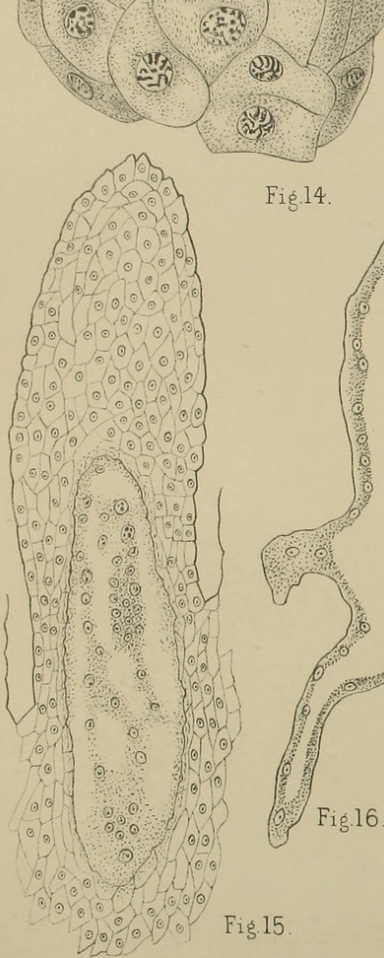

A. A awson del.

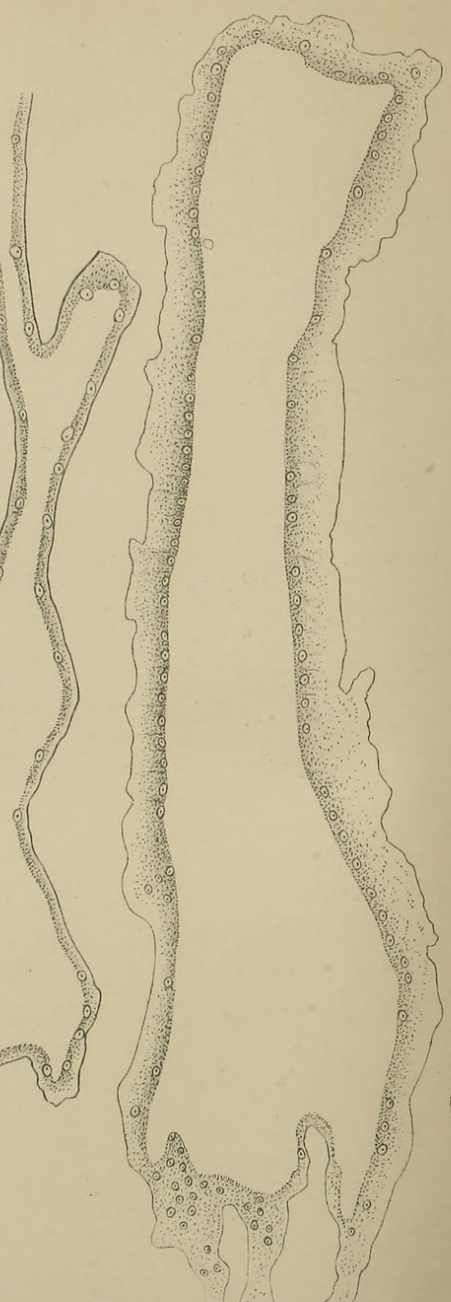

Fig.17.

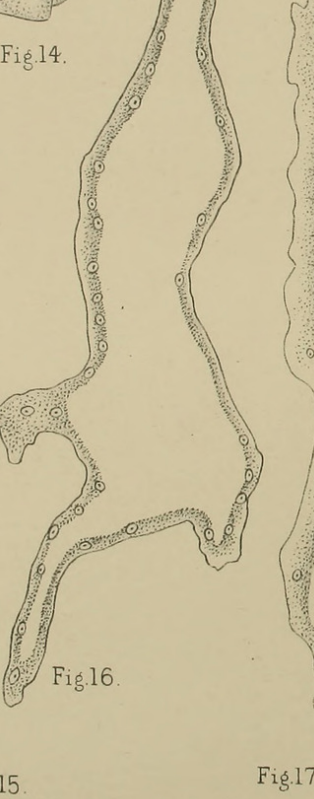

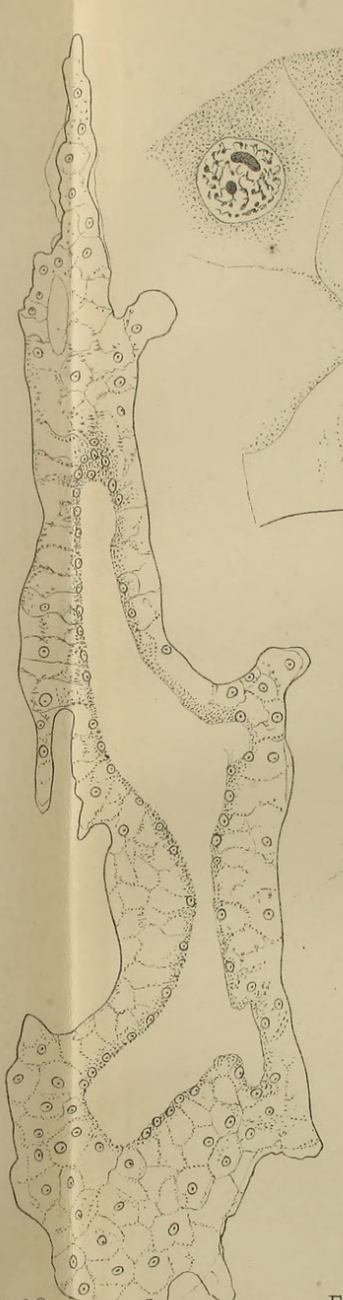

Fig.18.

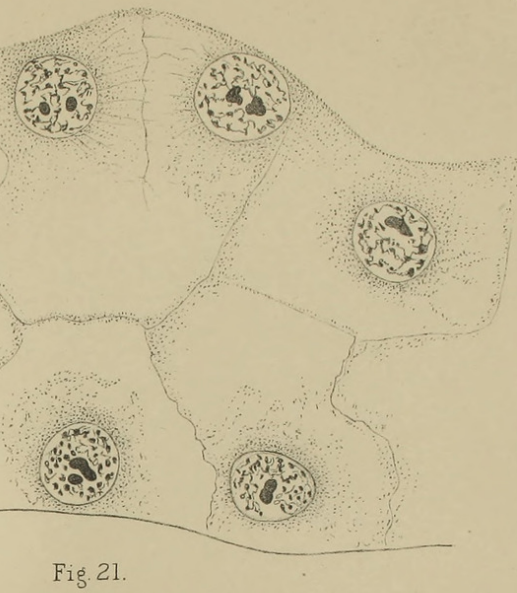

Vol. XVIII PI XXVIII.

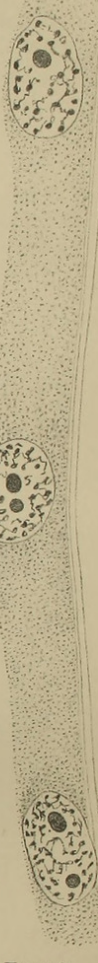

Fig. 22 .
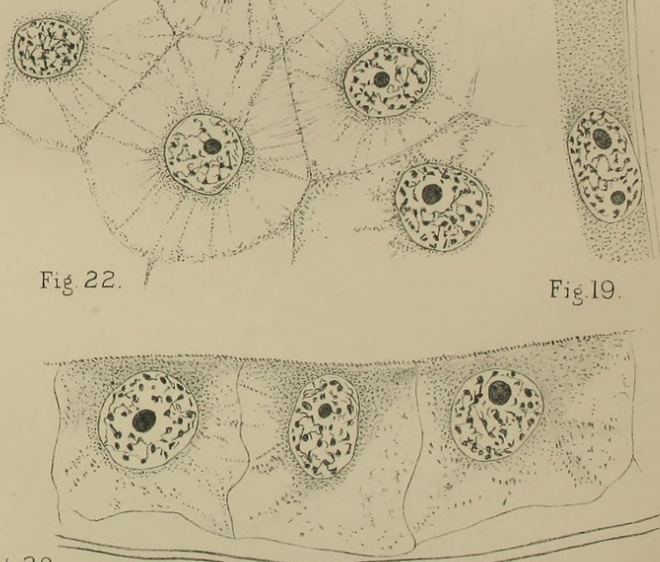
Annals of Botany.

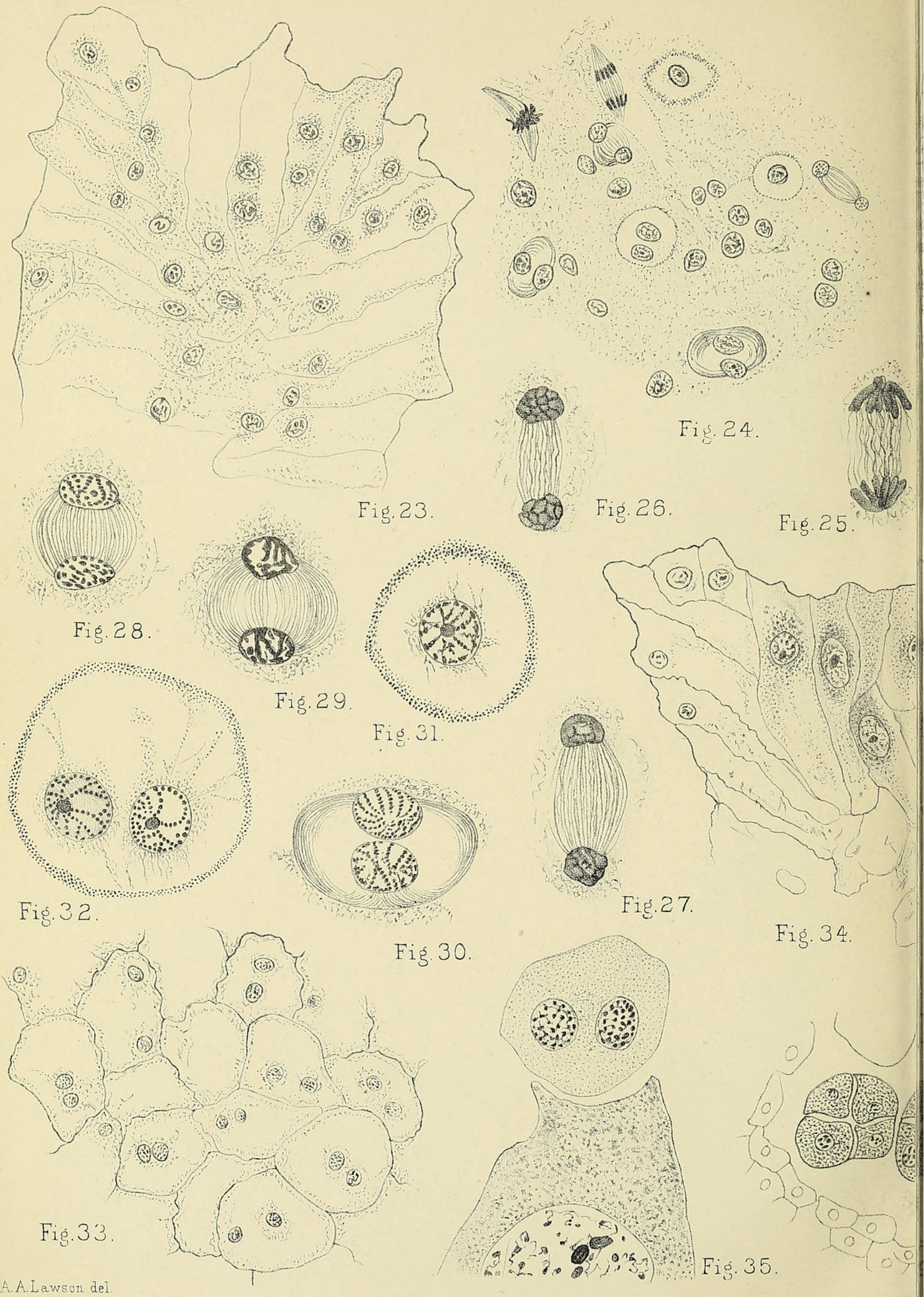

LAWSON.- CRYPTOMERIA JAPONICA. 


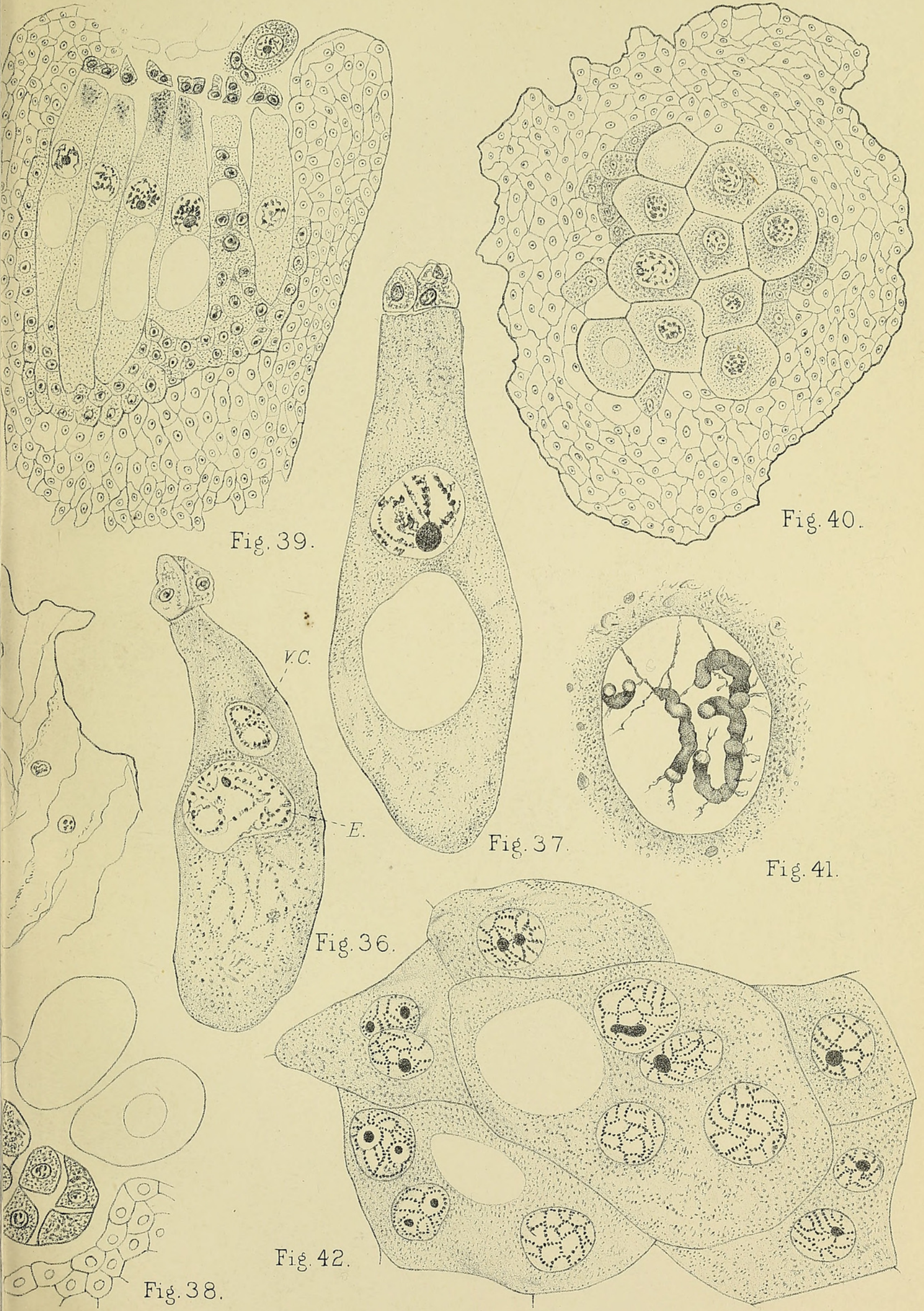



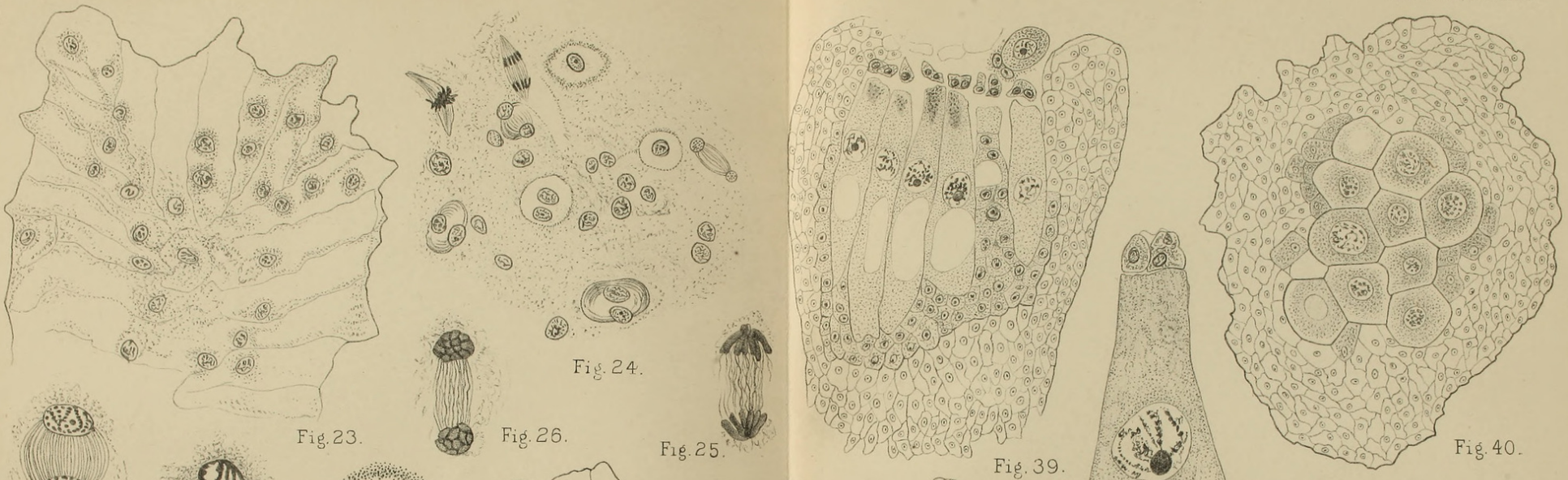

6
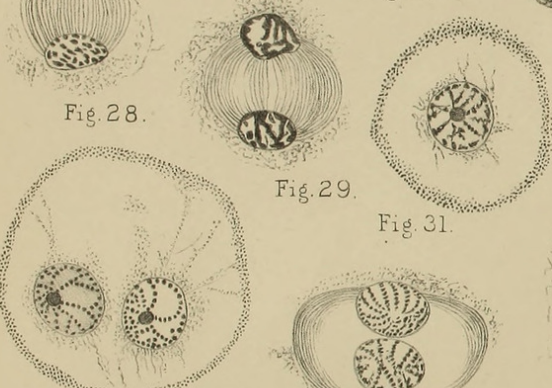

Fig.29.
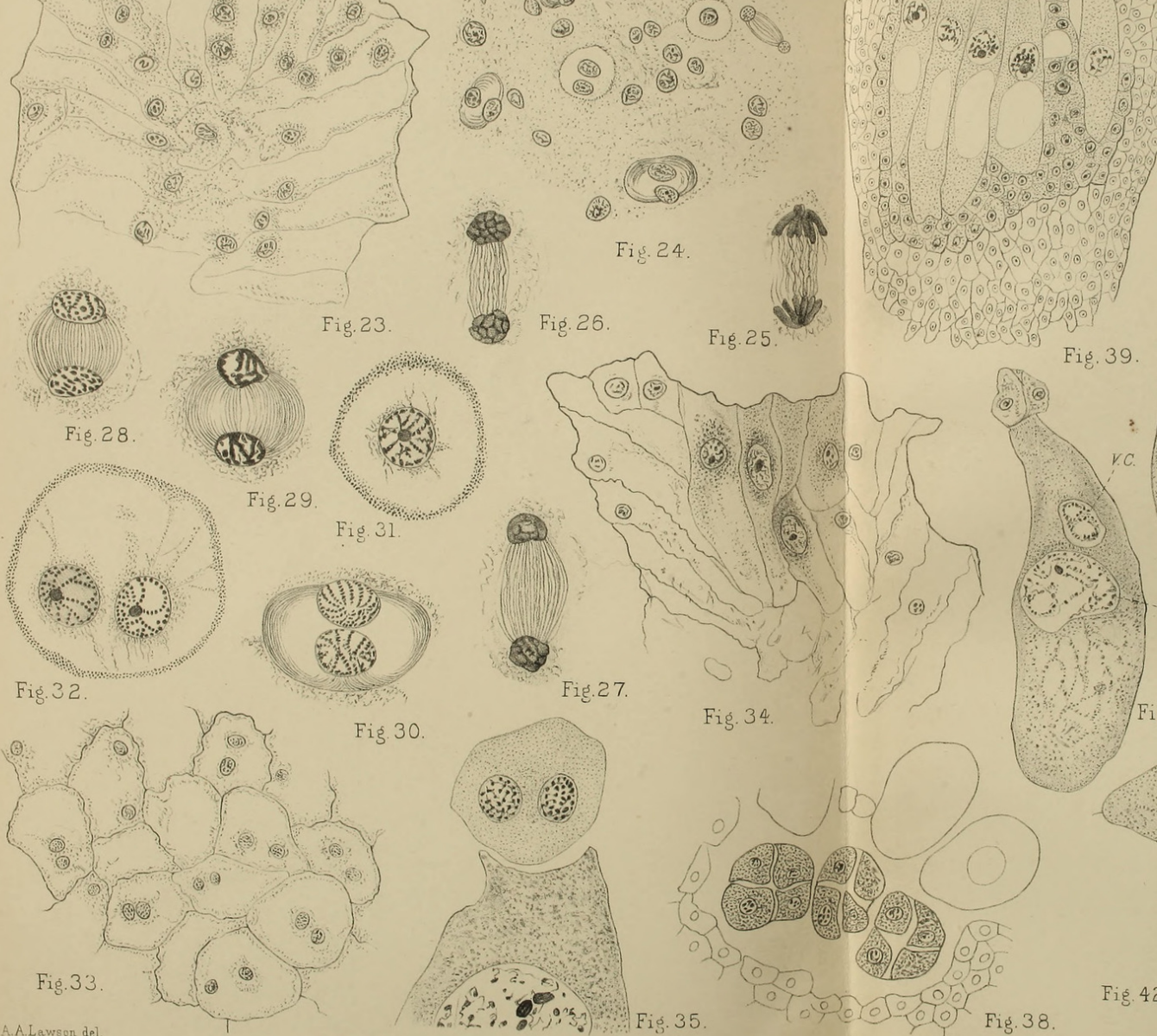

Fig. 27.

Fig. 34 .

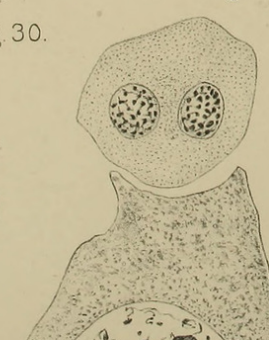

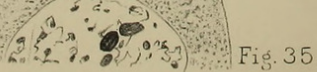
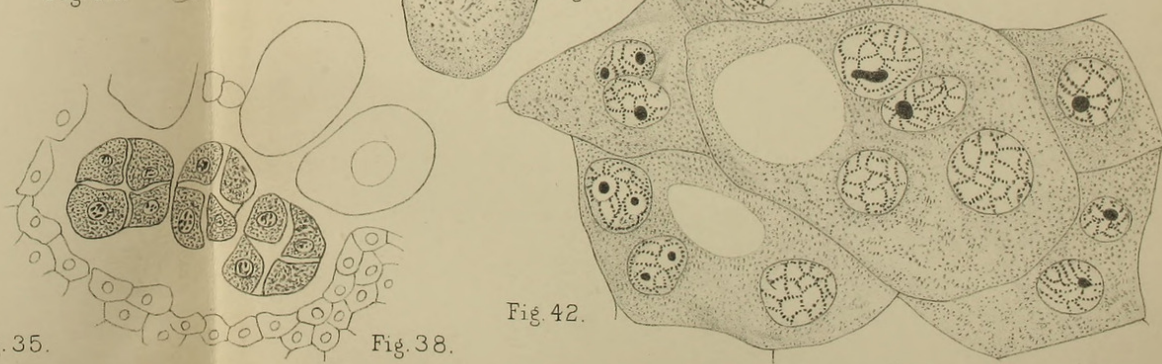
Annals of Botany.
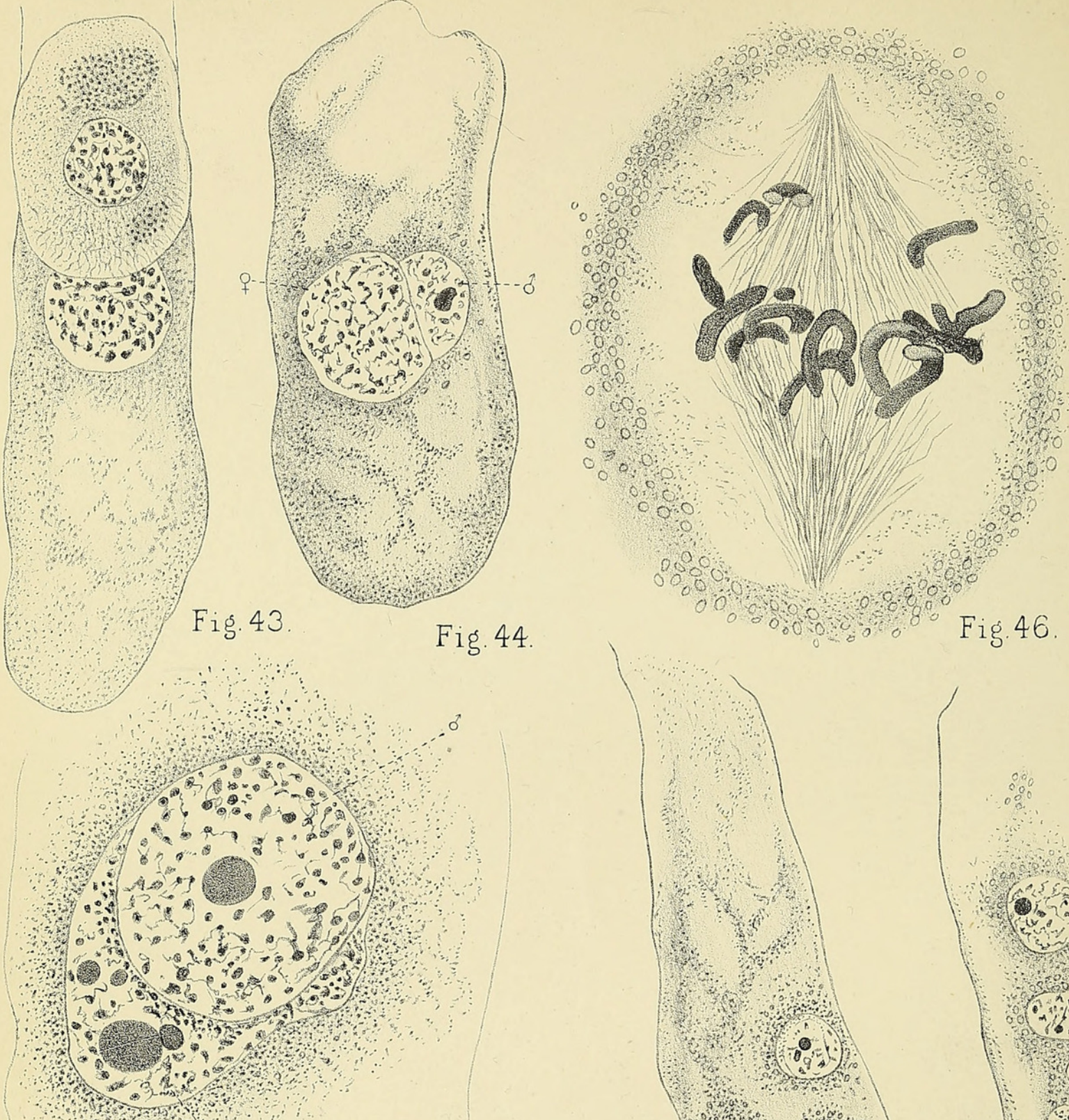

Fig. 45
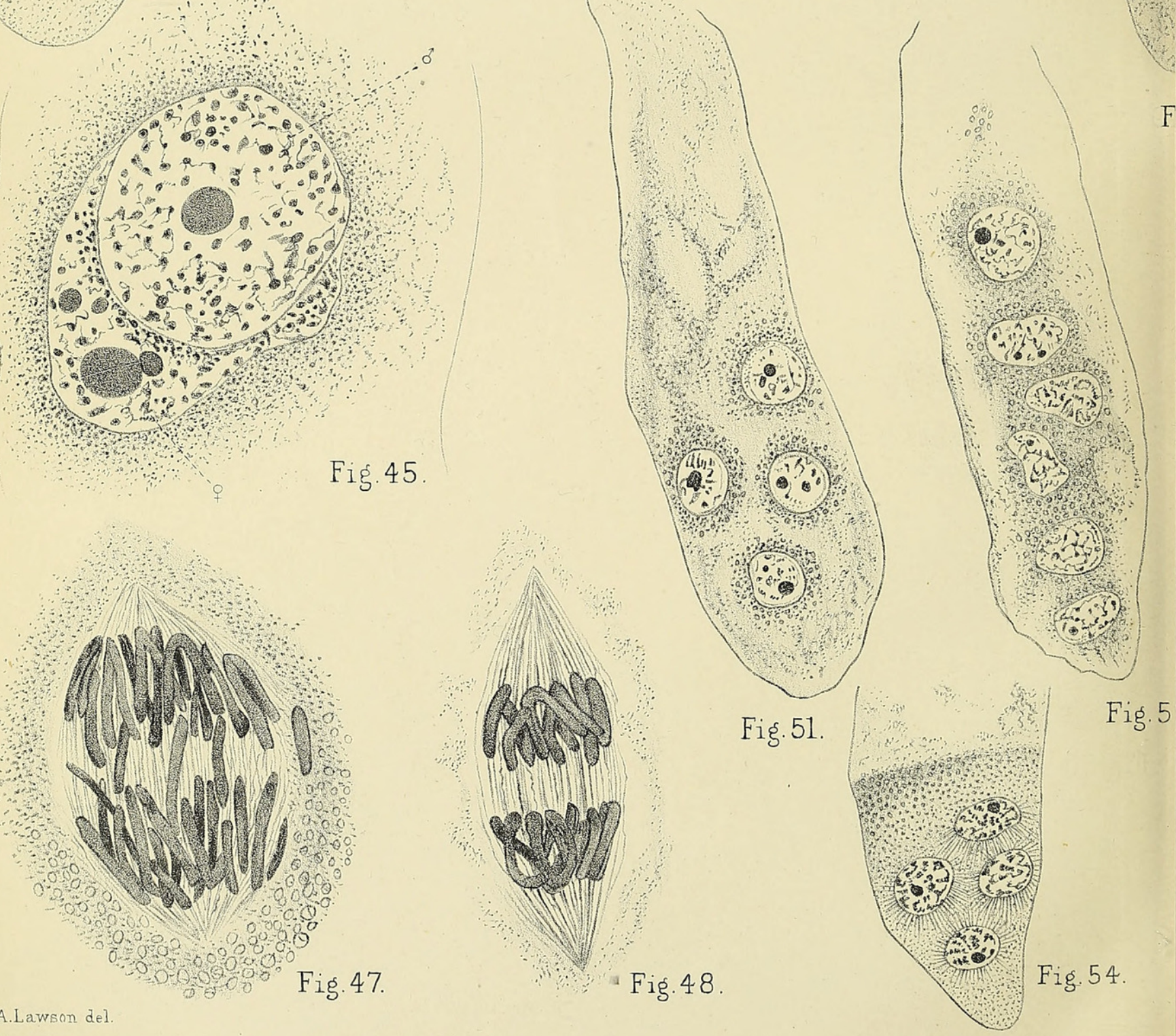


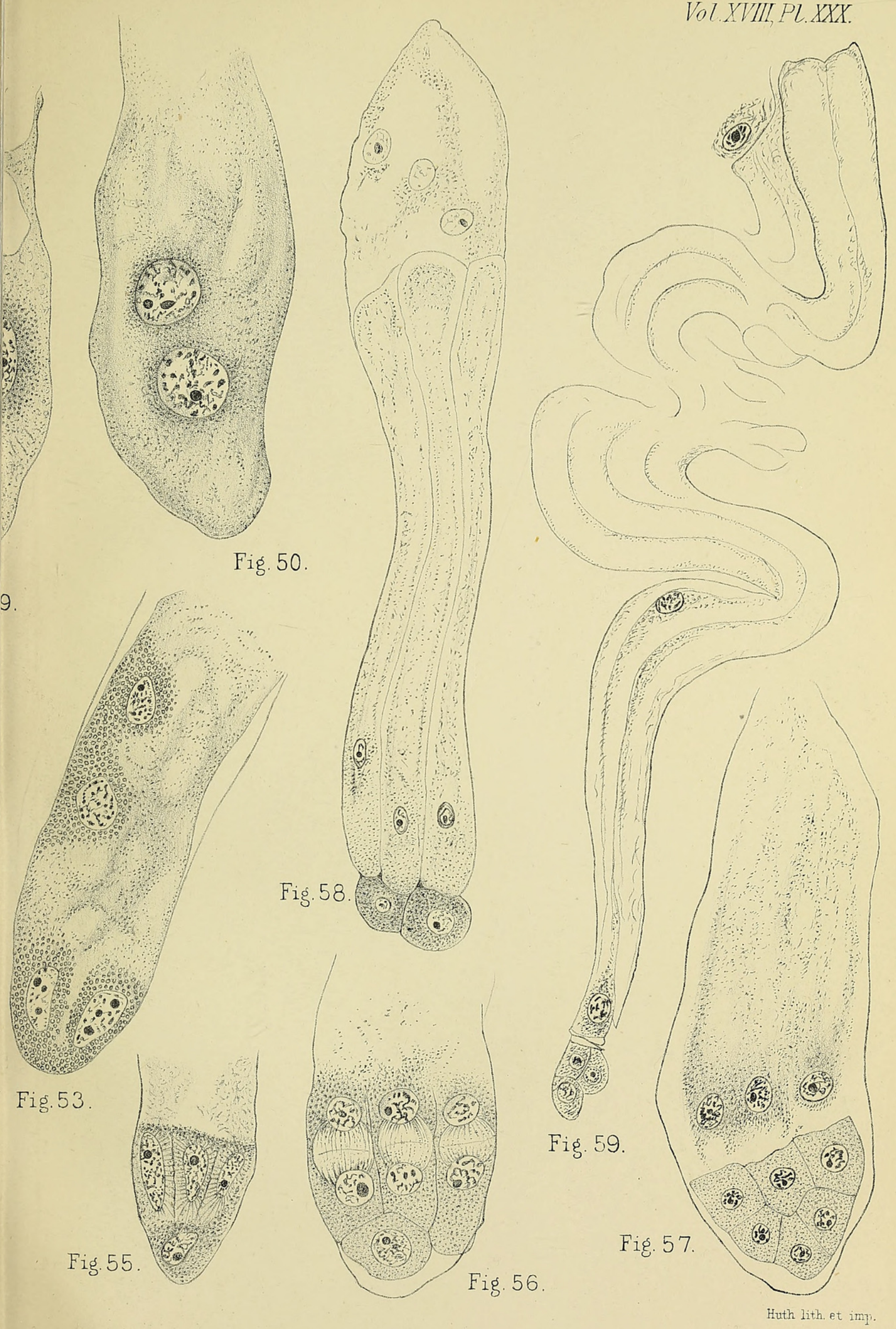


Annals of Botany.
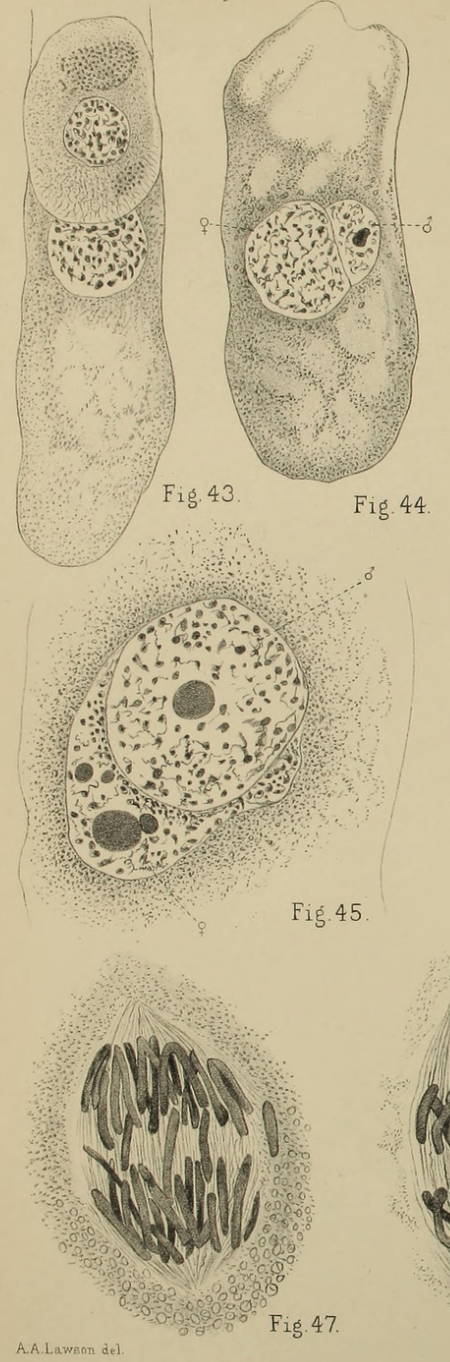
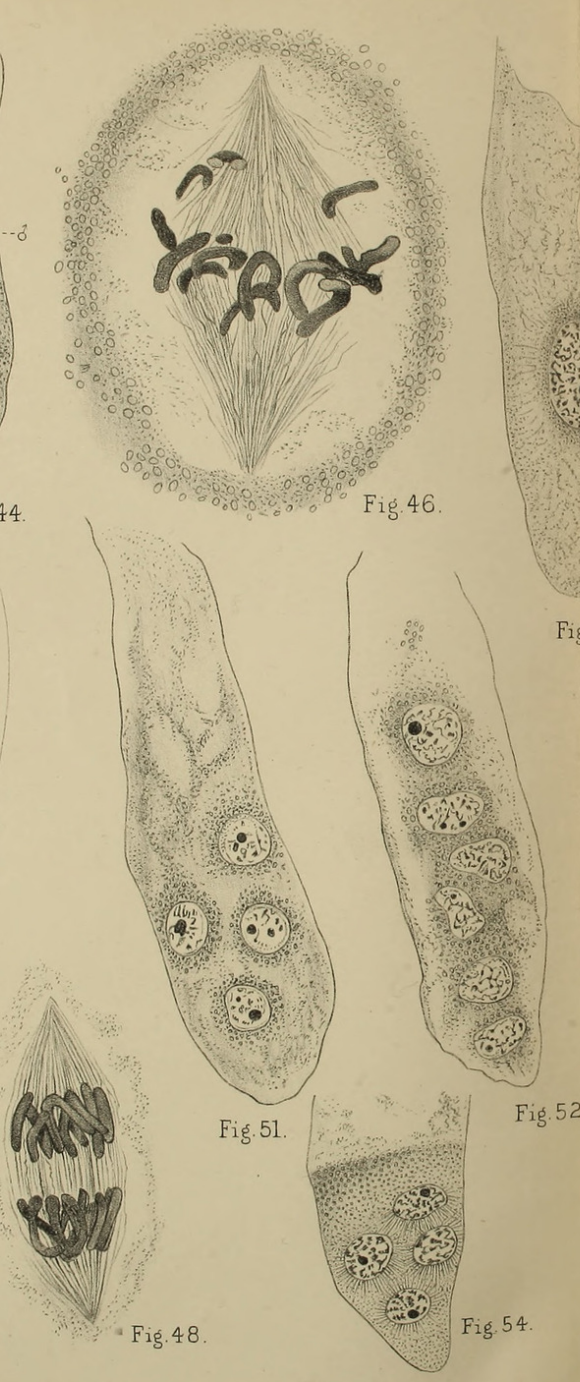

LAWSON.- CRYPTOMERIA JAPONICA.
Vol XVIII, PL. XXX.
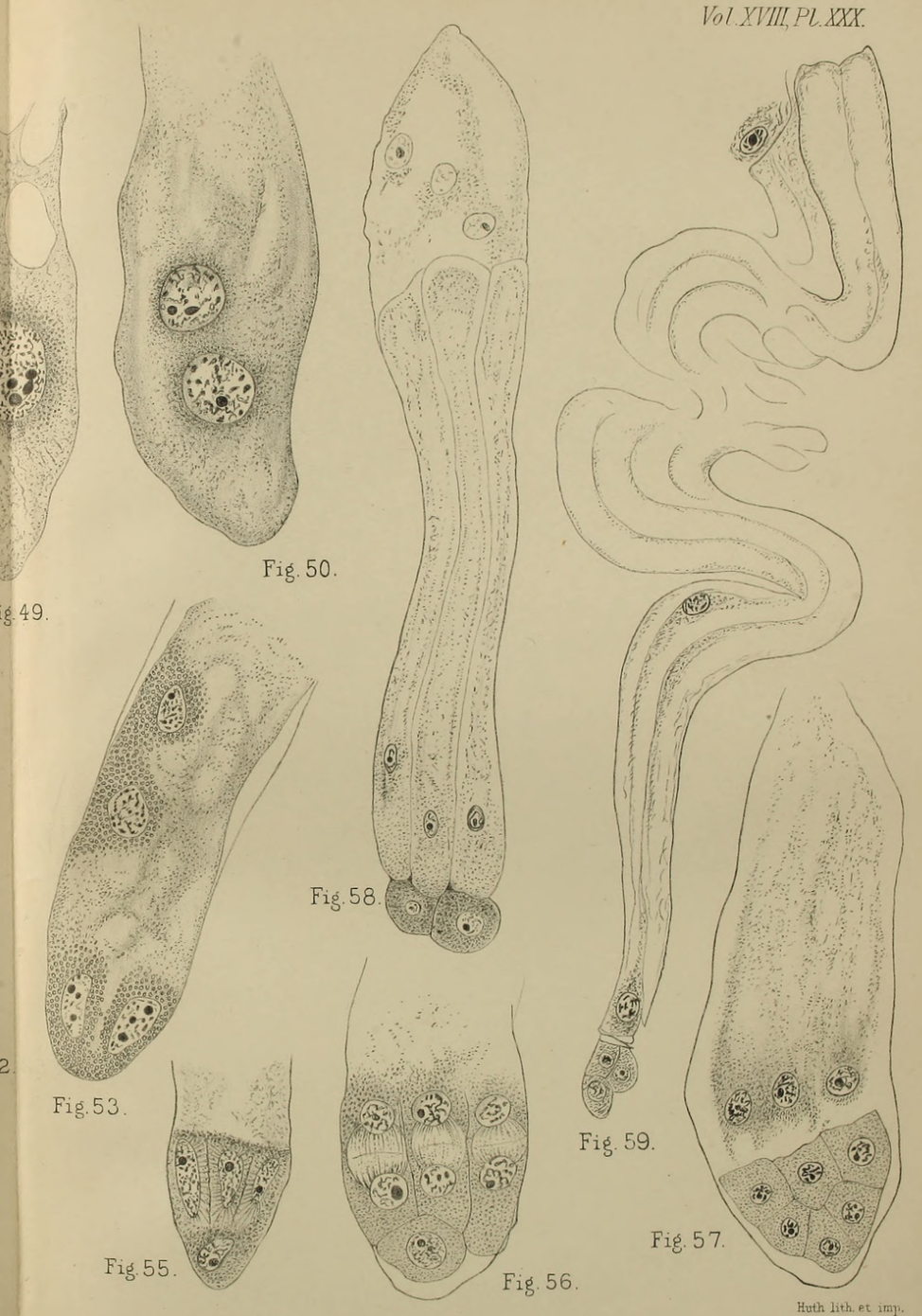


\section{$2 \mathrm{BHL}$ Biodiversity Heritage Library}

Lawson, Abercrombie Anstruther. 1904. "The gametophytes, fertilization and embryo of Cryptomeria japonica." Annals of botany 18, 417-444. https://doi.org/10.1093/oxfordjournals.aob.a088970.

View This Item Online: https://www.biodiversitylibrary.org/item/234469

DOI: https://doi.org/10.1093/oxfordjournals.aob.a088970

Permalink: https://www.biodiversitylibrary.org/partpdf/318767

\section{Holding Institution}

Smithsonian Libraries

\section{Sponsored by}

Biodiversity Heritage Library

\section{Copyright \& Reuse}

Copyright Status: Not in copyright. The BHL knows of no copyright restrictions on this item.

This document was created from content at the Biodiversity Heritage Library, the world's largest open access digital library for biodiversity literature and archives. Visit BHL at https://www.biodiversitylibrary.org. 